\title{
THE ROLE OF THE UNIVERSITY ADMINISTRATION IN PROMOTING OCCUPATIONAL SAFETY AND HEALTH IN LIGHT OF THE CORONA PANDEMIC
} http://dx.doi.org/10.47832/2757-5403.4-3.22

\section{May Faisal AHMED ${ }^{1}$ \& Nafez Mouhamed SHARAWI²}

\begin{abstract}
:
In this research, it is aimed to study the role of the university managers at two universities in promoting occupational safety and health by revealing whether there are statistically significant differences at the level of significance $\left(0.05^{*}\right)$. The researchers have looked at the role of university management in promoting safety and occupational health by looking at the following variables: sex, experience, and employability. The descriptive analytical approach has been used, and the developed questionnaire consists of 40 paragraphs, divided into four areas. The sample study has been randomly selected from the original research community, with the proportion of $14 \%$. The number of administrators and faculty members, who have been asked to fill up the questionnaire, has been 210 persons. The researchers have made sure that data variables are honest and stable. Results have been analyzed by using the SPSS program. The have reached many results and recommendations, and the most important ones are the following two: There must be a policy of awareness and guidance as well as adoption of specialized methods in occupational safety and health matters that promote the promotion of workers in the culture of occupational safety and health in order to take preventive measures, proper work and an appropriate educational environment in the mentioned universities. It is also urgent to form specialized committees in occupational safety and health to work on a clear policy with the preparation of crisis and disaster management plans mediated by a specified and experienced Committee and work on its application in the university institutions, especially nowadays under the Corona pandemic.
\end{abstract}

Key words: University Administration, The Corona Pandemic, Occupational Safety and Health.

\footnotetext{
${ }^{1}$ Dr. , Baghdad University, Iraq, memealyass21@gmail.com, https://orcid.org/0000-0001-7129-1405

${ }^{2}$ Researcher, Polytechnic University, Palestine, nafezs@ppu.edu, https://orcid.org/0000-0002-0122-5821
}

Copyright $(\odot)$ Published by IJHER Journal, www.ijherjournal.com Rimar Academy, Fatih, Istanbul, 34093 Turkey

All rights reserved 


\title{
دور الإدارة الجامعية في تعزيز السلامة والصحة المهنية في ظل جائحة كورونا
}

\author{
مي فيصل أحمد 3 \\ نافذ محمد عبد الرحمن الثعراوي
}

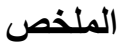

دراسة ميدانية هدفت إلى معرفة دور الإدارة الجامعية في تعزيز السلامة والصحة دالصة المهنية

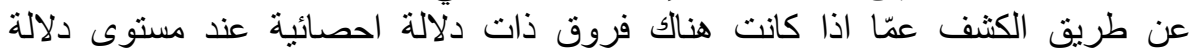

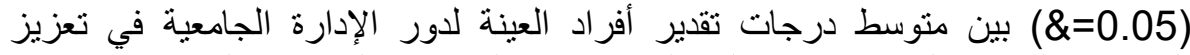

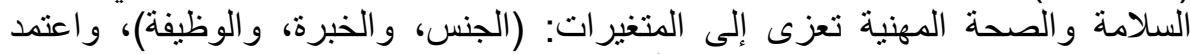

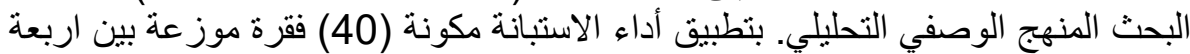

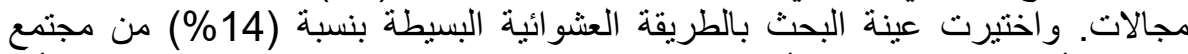

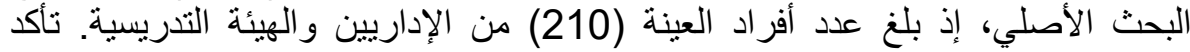

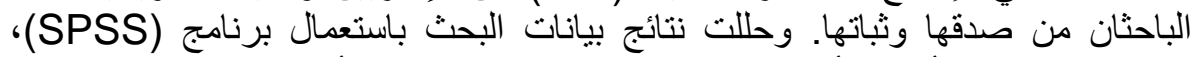

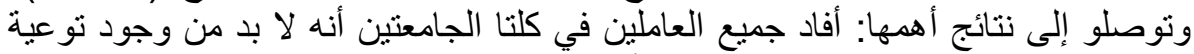

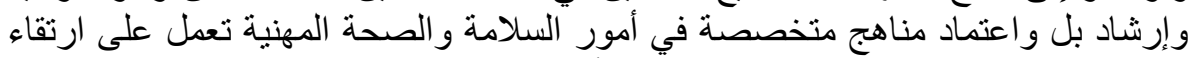

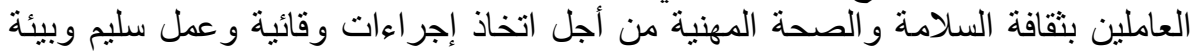

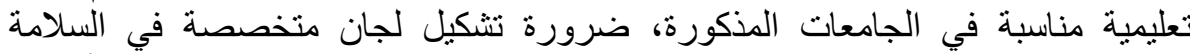

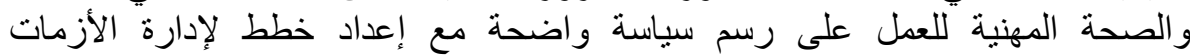

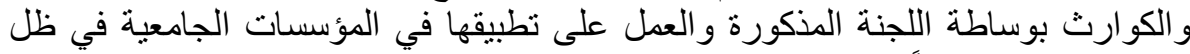

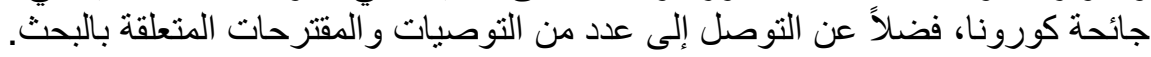

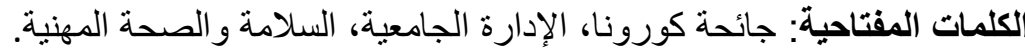

\section{مشكلة البحث:}

يعد العنصر البشري الثروة الحقيقة والدحور الأساسي للإنتاج في مواقع العمل المختلفة، فالأجهزة والأدوات والآلات

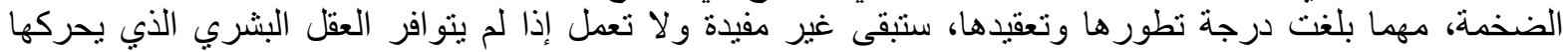

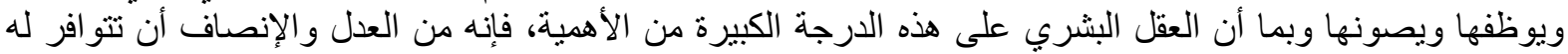

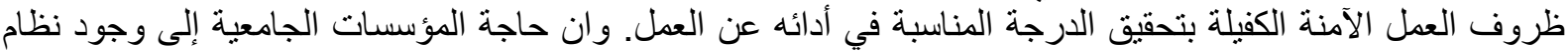

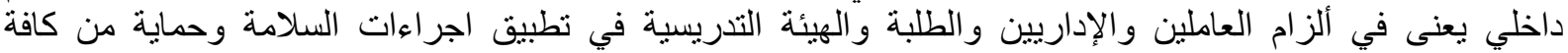

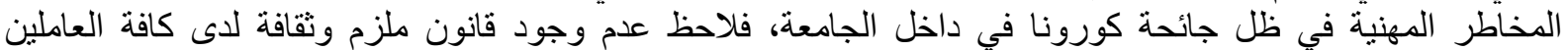

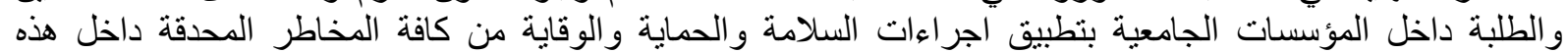

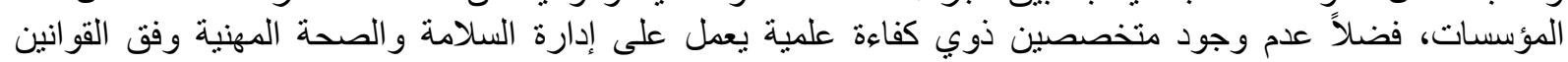

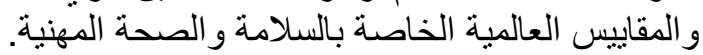

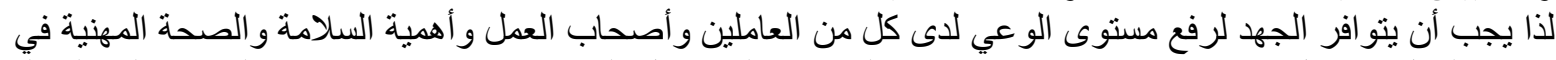

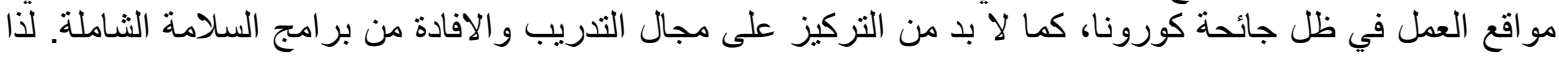

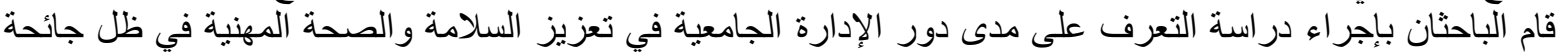

يمكن تلخيص الأهمية بالنقاط الآتية:

1- توضح الدراسة مدى احتياج إدارة الجامعية لنتائج هذه الدراسة التي من شأنها القيام بتطوير قو اعد وإجراءات السلامة و الصحة المهنية.

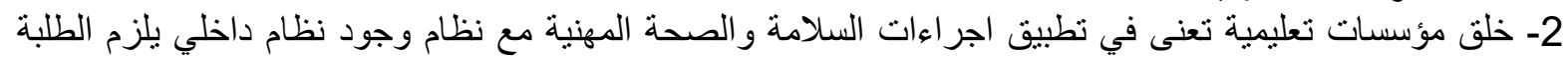

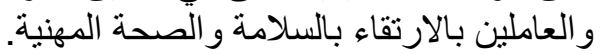

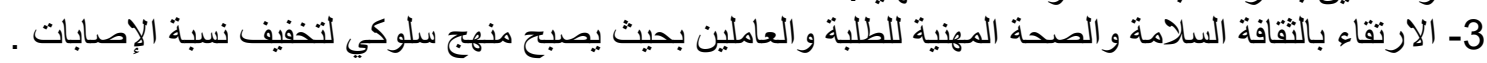




\section{THE ROLE OF THE UNIVERSITY ADMINISTRATION IN PROMOTING OCCUPATIONAL SAFETY AND HEALTH IN LIGHT OF THE CORONA PANDEMIC}

4- إلتزام الإدارة الجامعية بتطبيق قو اعد السلامة و الصحة المهنية تؤدي إلى زيادة التحصيل العلمي و الكفاءة العلمية.

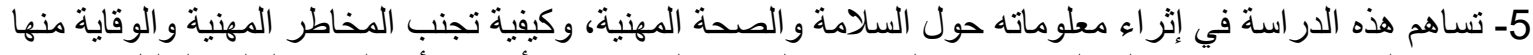

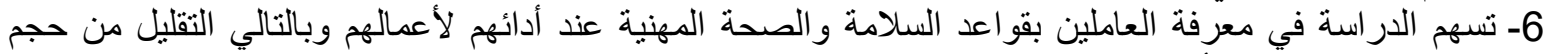
الخسائر سواء المادية أو البشرية في الجامعة فئمة

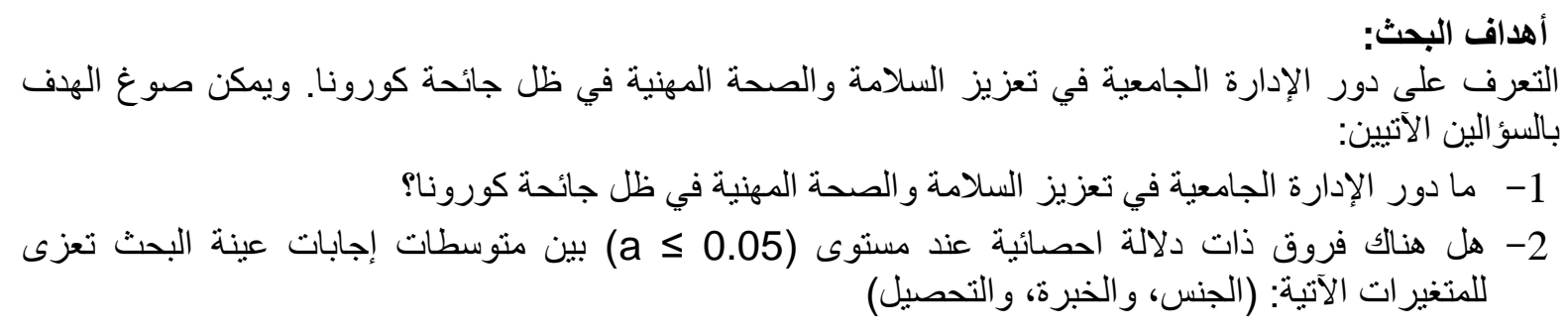

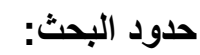

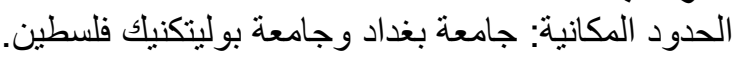

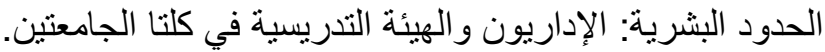
الحدود الزمانية: الفصل الاول للعام الدراسي 2021/2020.

تحديد المصطلحات:

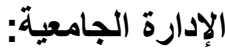

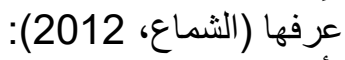

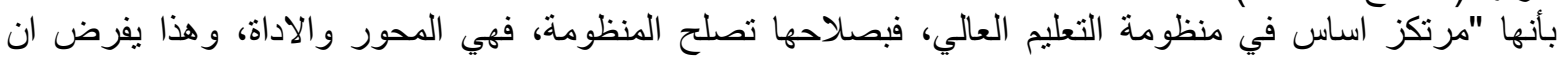

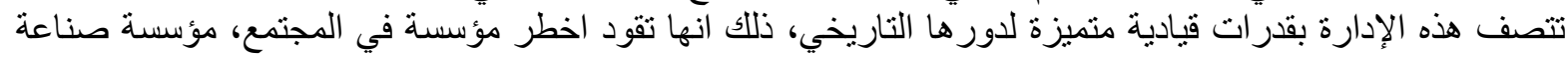

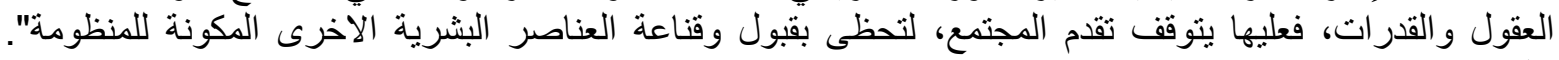

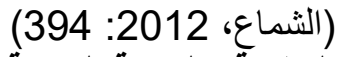

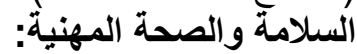

ـ عرفها (عباس، 2003):

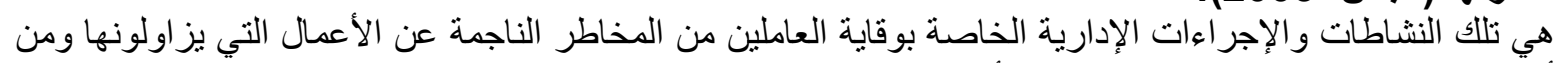

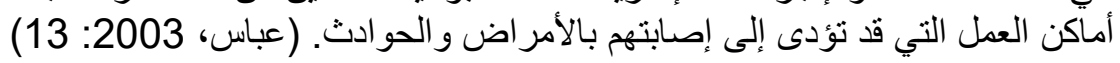

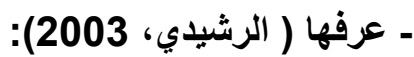

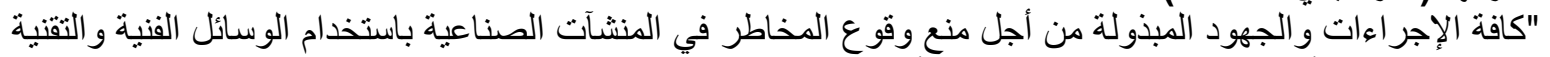

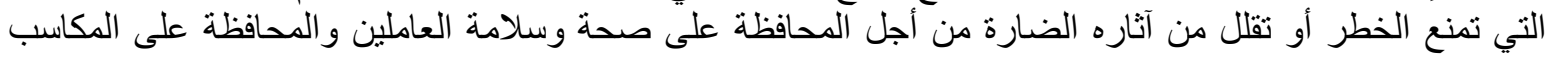

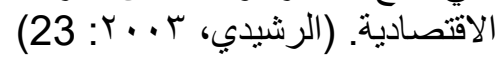

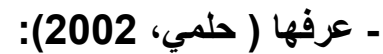

كل إجراء يتخذ للحد أو لتخفيض من حوادث إث العمل والأمر اض المهنية أو تقديم وسائل الوقاية والإسعاف مع توفير

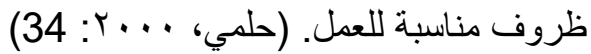

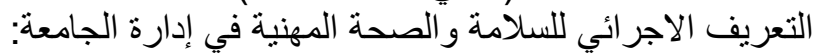

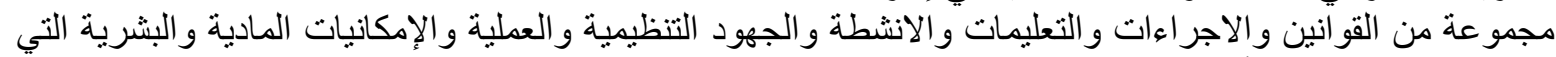

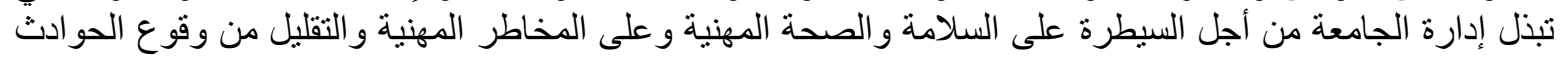

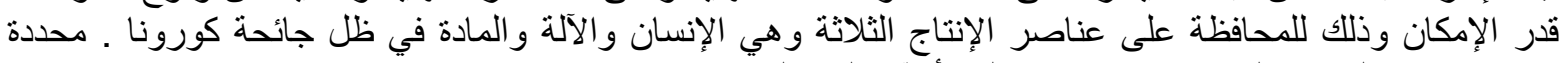

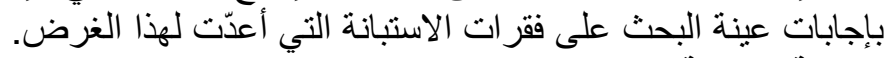

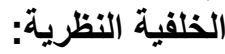

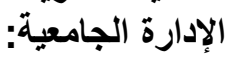

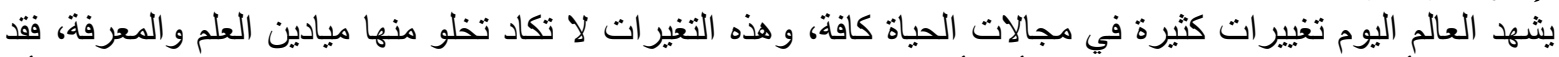

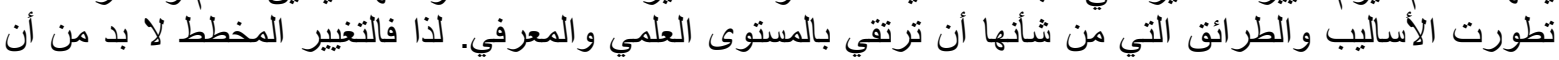

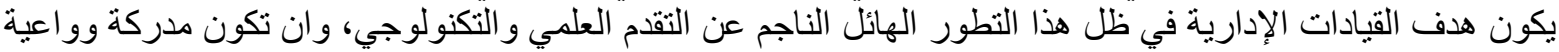

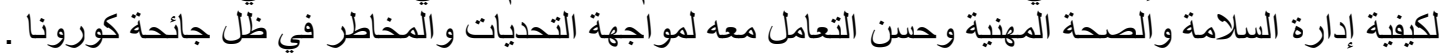


إن الهدف الأساسي لإدارة أي مؤسسة يكمن في توجيه العاملين فيها وتنظيمهم بهدف تحقيق تفعيل جيد لمدخلاتها كافة

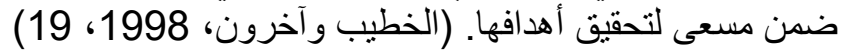
وقد اهتم الباحثون في إعطاء مفاهيم وأسس للإدارة الجامعية لكي يكون التعليم الجامعي أداة فعالة في صنع المستقبل

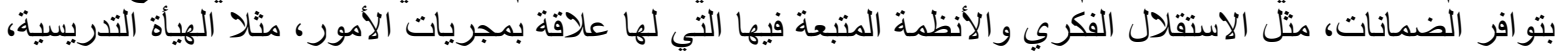

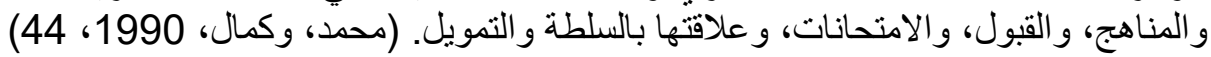
و لا بد من الاختيار الكفء للموارد البشرية بحيث تكون لها القدرة ومهارة التخطيط في المستقبل ولئل وفي مجالات الإدارة

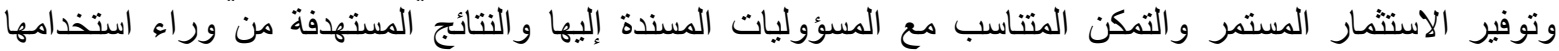

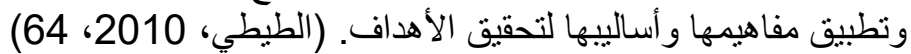
ومن أهداف الإدارة الجامعية: ـ اعتماد الكفاءة في القيادة الجامعية.

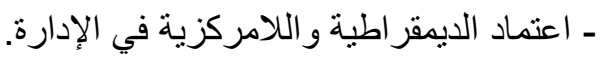
ـ أن تشرك اعضاء هيئة التدريس في الإدارة.

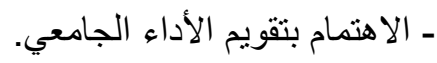

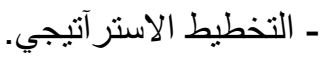
ـ - الحرية الاكاديمية للتنريسي.

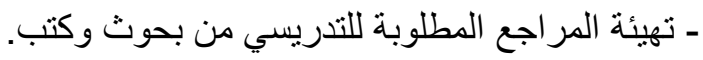
- ت تمويل بحوث التدريسيين.

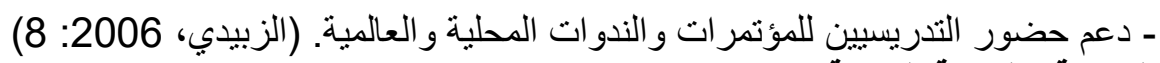
السلامة والصحة المهنية:

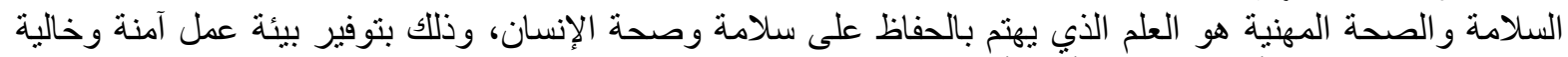

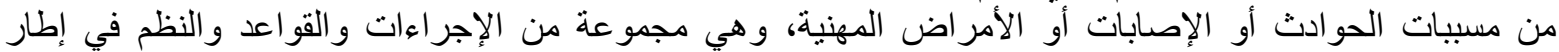

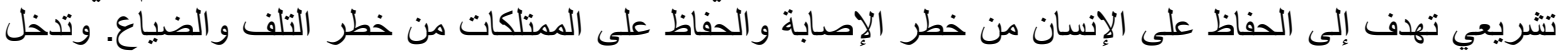

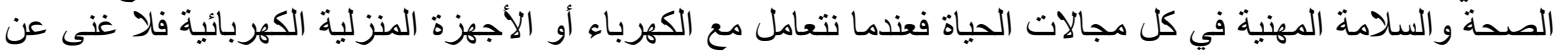

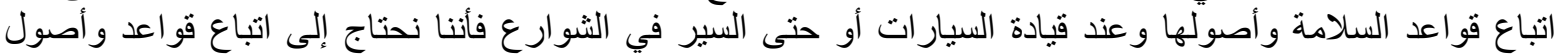

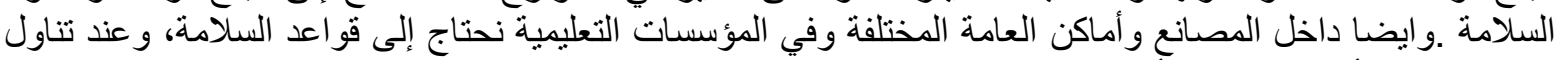

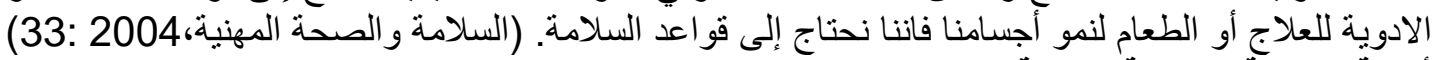
أهمية السلامة والصحة الصادية المهنية: 1. تقليل تكاليف العمل: إن الإدارة السليمة لبيئة العمل تجنب المنظمة الكثير من التكاليف المادية والمعنوية المتضمنة

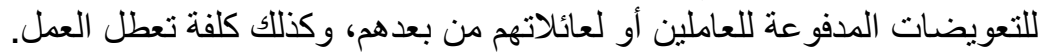

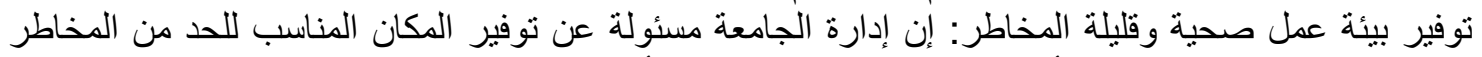

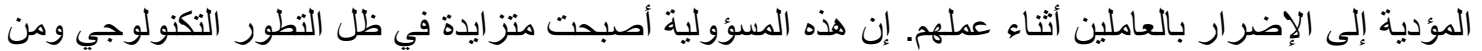

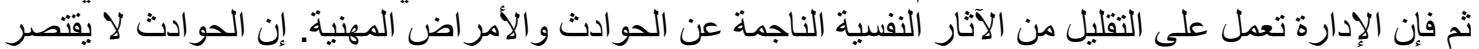

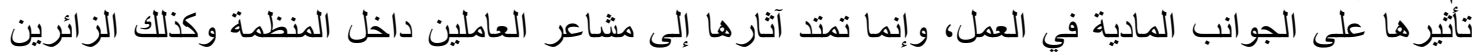

3. توفير نظام العمل المناسب: يتم توفير نظام العمل من خلال توفير الأجهزة والمعدات الواقية واستخدام السجلات

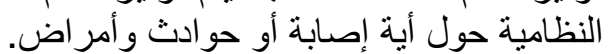

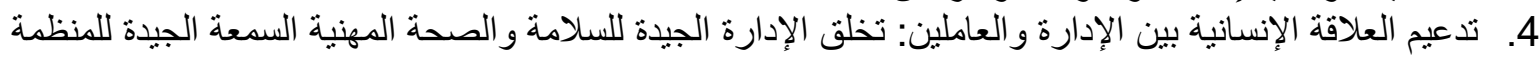

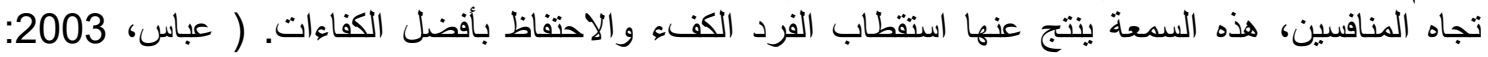

1 - حماية العناصر البشرية للإنتاج من الأضرار الناتجة عن مخاطر العمل وظروف البيئة، وذلك عن طريق إزالة

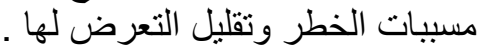

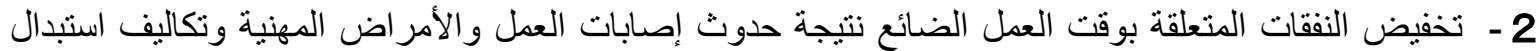

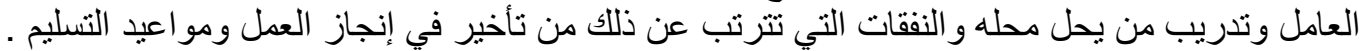

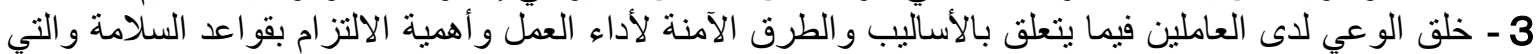

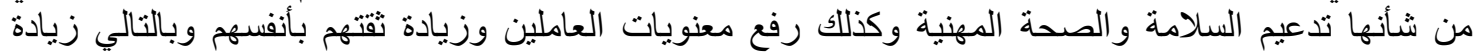




\section{THE ROLE OF THE UNIVERSITY ADMINISTRATION IN PROMOTING OCCUPATIONAL SAFETY AND HEALTH IN LIGHT OF THE CORONA PANDEMIC}

4 - توفير بيئة عمل آمنة تحقق الوقاية من المخاطر لمستخدمي المختبرات العلمية والعاملين فيها، وذللك بإيجاد

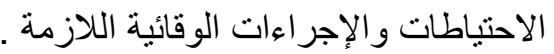

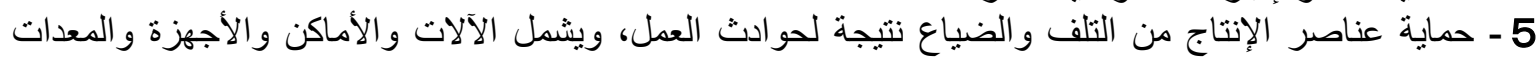

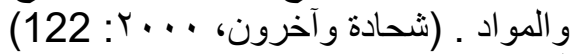

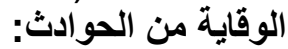

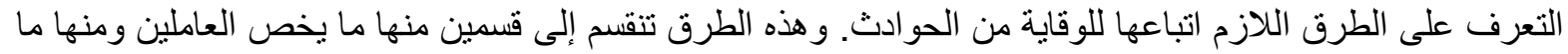

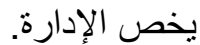

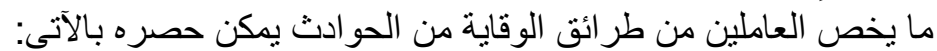

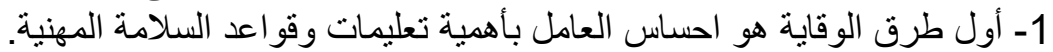

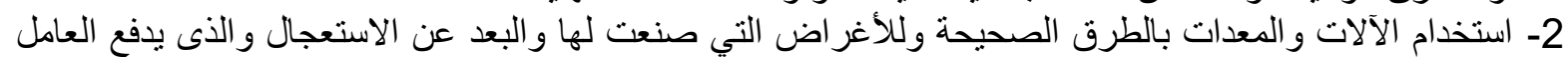

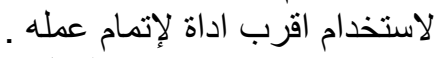

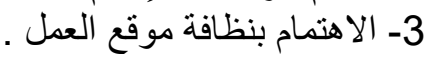

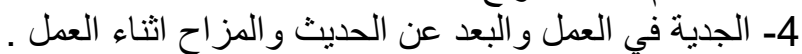
5- الانتباه إلى العلامات الارشادية و التحذيرية سواء الصوات الصوتية أو الضوائية أو التي على شكل شر ائط ملصقة

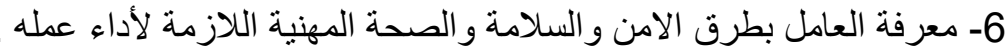
7- أن معرفة العامل بمنطلبات الأمن و السلامة للمهنة التي يعمل بها يجعله قادر العلى على مطالبة الإدارة بتأسيس بيئة العمل

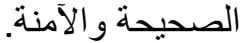
8- اهتمام العامل بصحته الجسدية و النفسية مما يزيد من تركيزه اثناء العمل وبالتالي تناقص فرص الخطأ الثناء التاء العمل

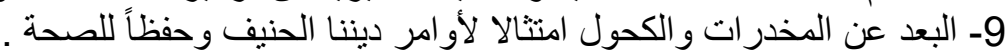

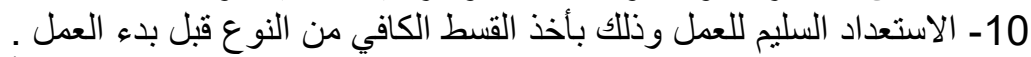

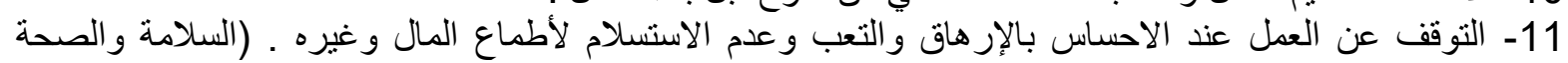

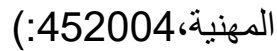
طرق الوقاية التى يمكن ان تانتخذها (الإدارة الجامعية فهى:

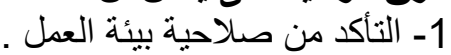

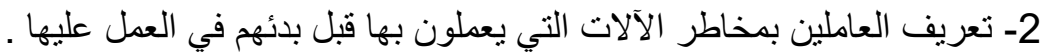

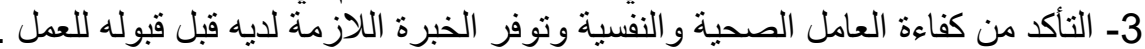

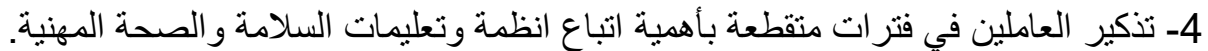

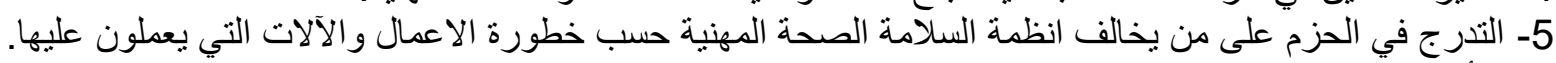

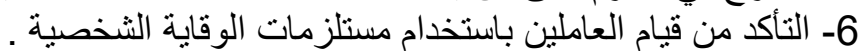

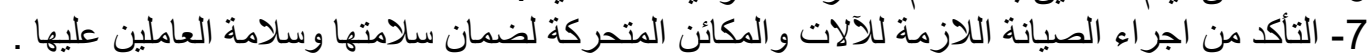

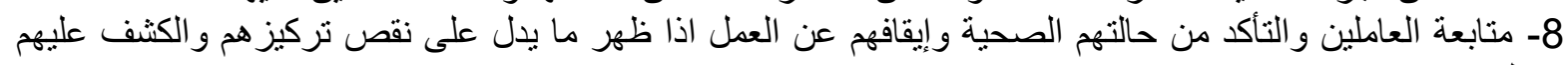

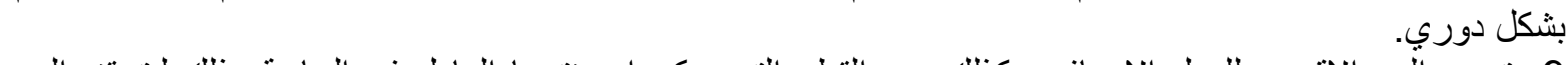
9- تحديد الحد الاقصى للعمل الاضافي وكذللك عدد القطع التي يمكن ان ينتجها العامل فى الساعة وذللك ليتحقق الحد

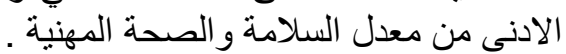

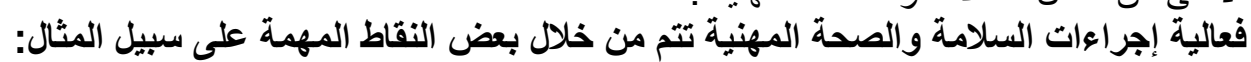

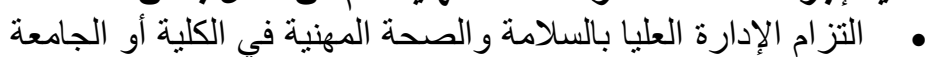

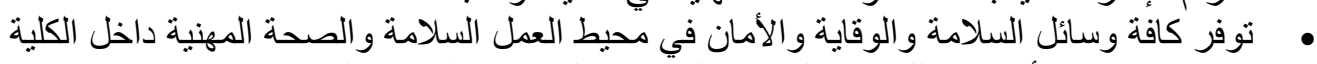

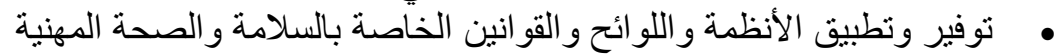

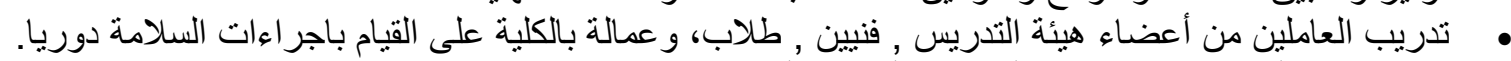

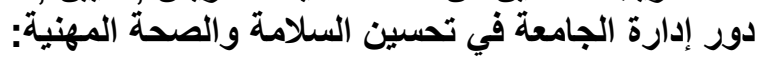

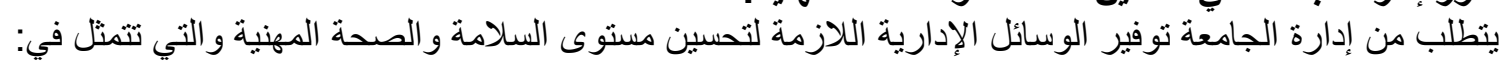
1- نوفير كادر متخصص في أمور السلامة العامة على مسنوى الجامعة.

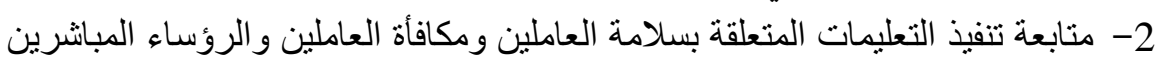

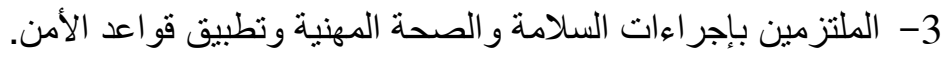
4- عقد ورش عمل ودورات في وسائل السلامة العامة للعاملين. 5- تثبيت لوحات إرشادية وتحذيرية في مختلف مو اقع العمل. 


\section{6- القيام بجو لات للتأكد من قيام العاملين بتطبيق إجر اءات السلامة المهنية. \\ 7- متابعة إصابات العمل في مختلف المو اقع و إعداد التقارير الدورية.

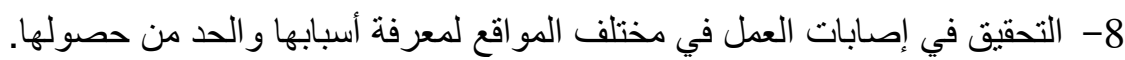

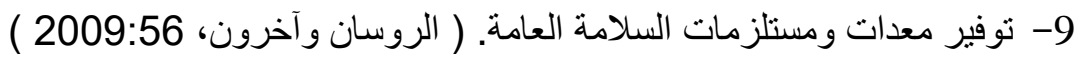

دراسات سابقة:

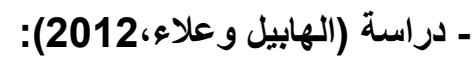
عنوان الدراسة ((تقييم مدى فعالية إجراءات السلامة والصات الصحة المهنية في المختبرات العلمية من وجهة نظر العاملين))

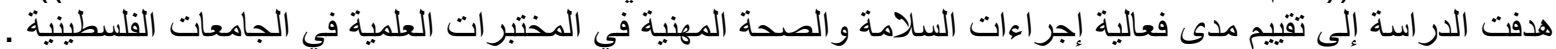

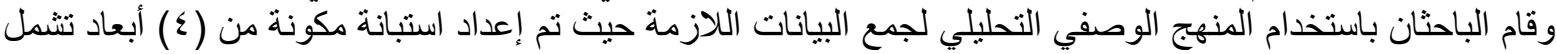

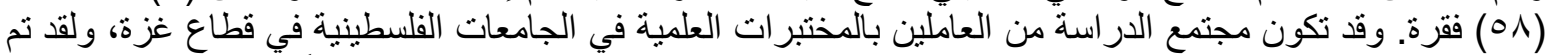

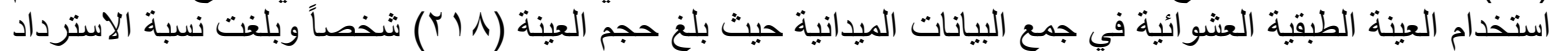

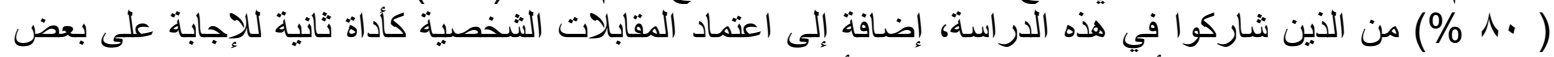

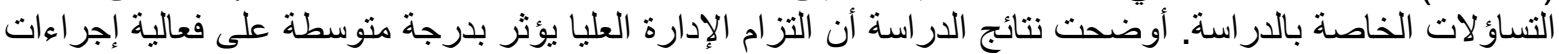

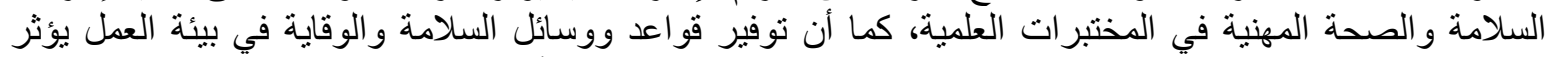

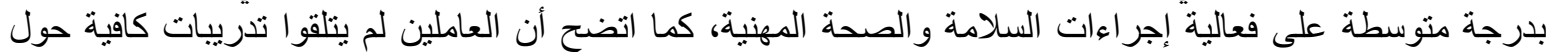

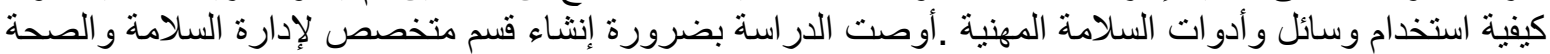

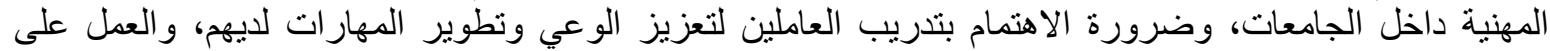
تطبيق كافة القو انين و اللو ائح المتعلقة بسلامة وحماية العاملين داخل المختبرات العلمية ولطية وتفعيل أنظمة السلامة داخل

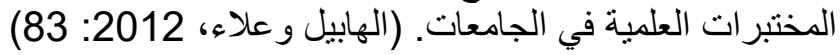

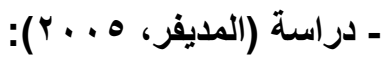
بعنوان " مدى فاعلية تطبية فيبق أنظمة الأمن والسلامة المهنية والتقنية دراسة مسحية على معامل الأقسام العلمية بكليات

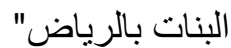

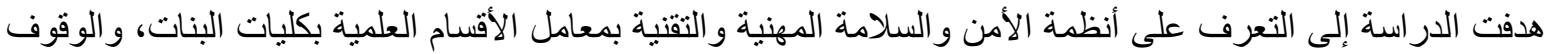

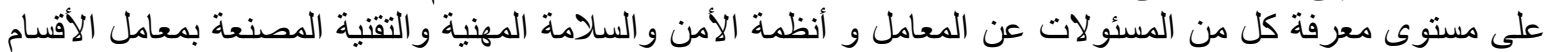

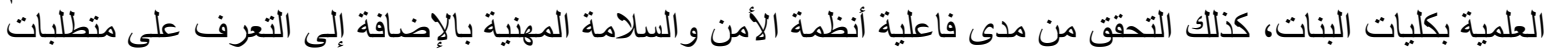

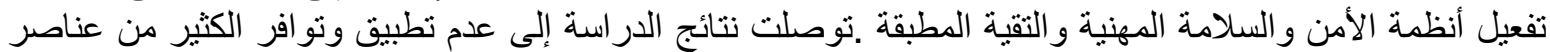

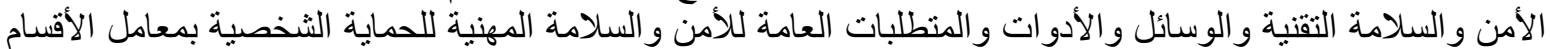

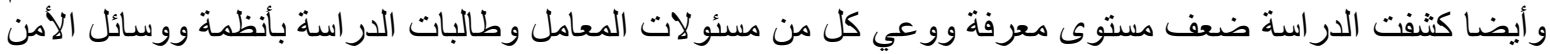

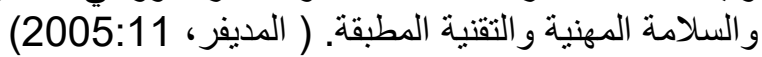

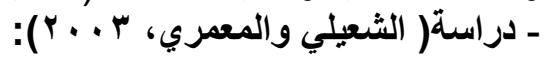

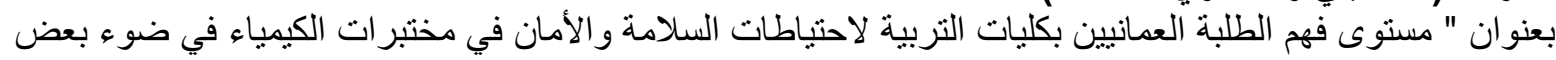

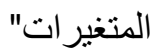
هدفت هذه الدر اسة إلى الكثف عن مستوى فهم طلبة كليات التربية بسلطنة عمان ـ تخصص الكئن الكيمياء - لاحتباطات

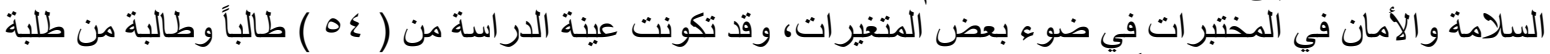

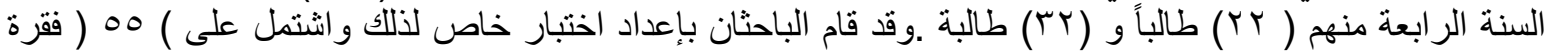

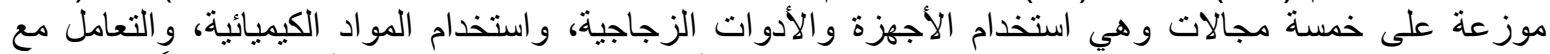

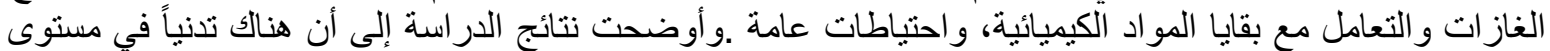

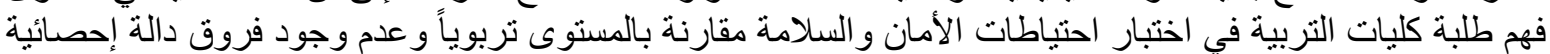

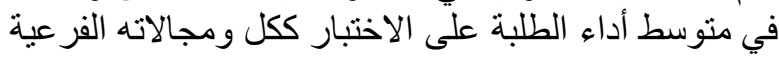

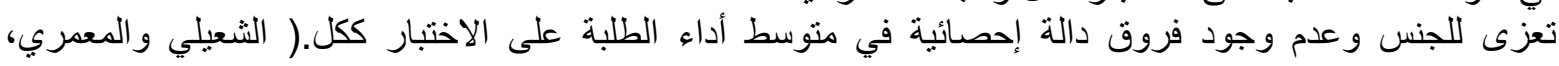

ـ دراسة ( احمد وآخرون،2015): عنوان " تقويم خدمات الصحدة المرونية آلصنية والبيئة في الجامعات العربية:نموذج " مركز خدمات الصحة المهنية و البيئة

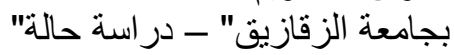

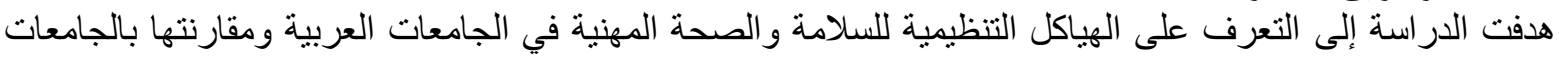

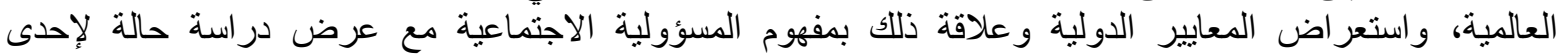




\section{THE ROLE OF THE UNIVERSITY ADMINISTRATION IN PROMOTING OCCUPATIONAL SAFETY AND HEALTH IN LIGHT OF THE CORONA PANDEMIC}

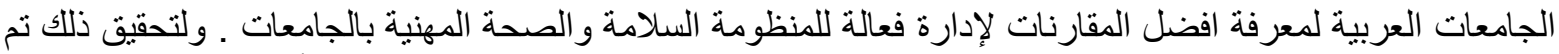

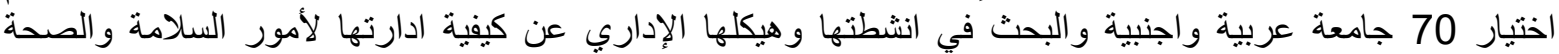

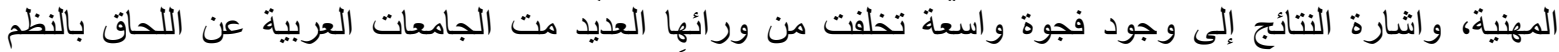

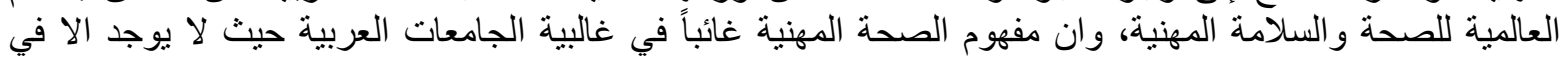

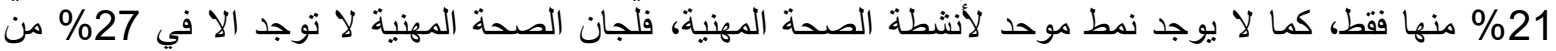

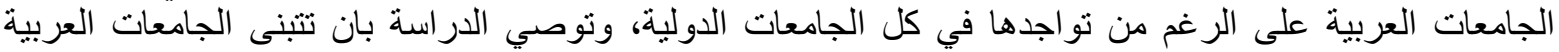

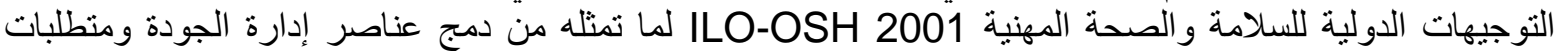

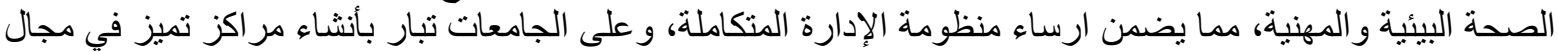

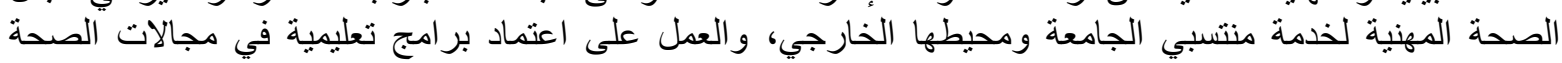

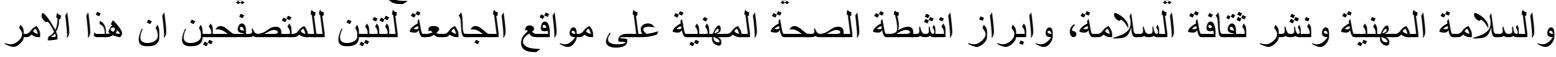

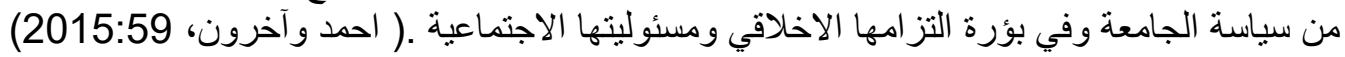

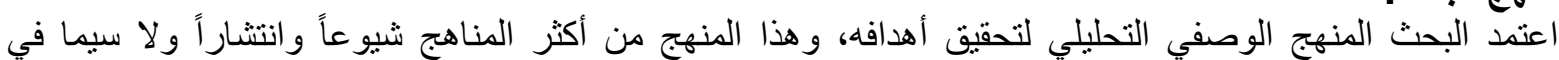

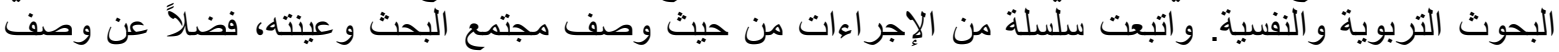
الأداة المستعملة و إيجاد الصدق و الثبات للأداة، وتحديد الوسائل الإحصائية الملائمة التي استعملت في تحليل البيانات من

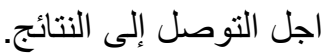

مجتمع البحث وعينته:

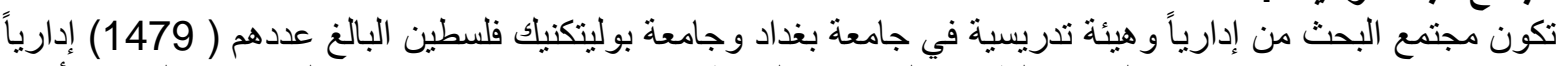

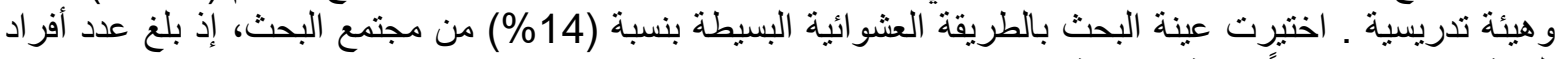
العينة ( 210 ) إدارياً و هيئة تدريسية.

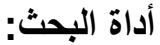
اعتمدت الباحثان الاستبانة مصدر اً اساسياً في جمع المعلومات لاستكمال منطلبات الجانب العملي و الوصول إلى النتائج،

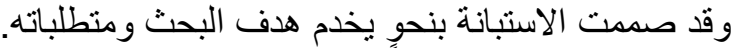

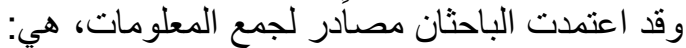

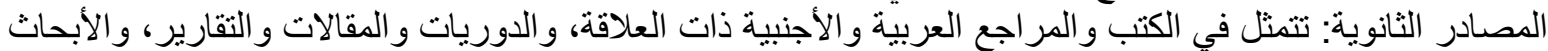

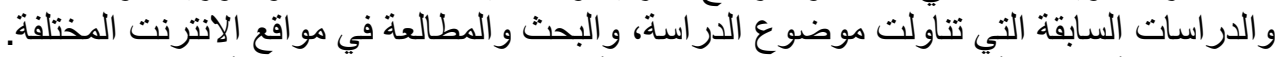

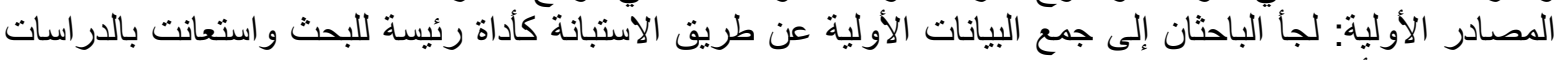

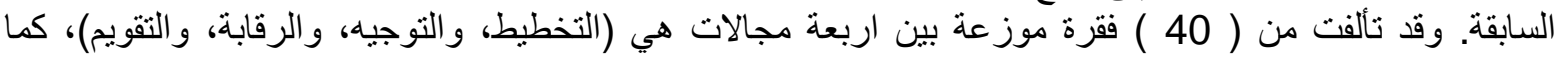
موضح في الجدول (1) من منالفن

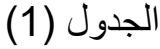
توزيع الفقز ات على وفق مجالات الاستبانة

\begin{tabular}{|c|c|c|c|}
\hline النسبة المئوية & عدد الفقرات & المجالات & ت \\
\hline 25 & 10 & التخطبط & -1 \\
\hline 25 & 10 & التوجيه & -2 \\
\hline 25 & 10 & الرقابة & -3 \\
\hline 25 & 10 & التقويم & -4 \\
\hline$\% 100$ & 40 & المجموع & \\
\hline
\end{tabular}

وبعد الانتهاء من صوغ فقرات الأداة بصورتها الأولية وضع مقياس ثلاثي متدرج (مو افق بدرجة كبيرة، ومو افق درجة

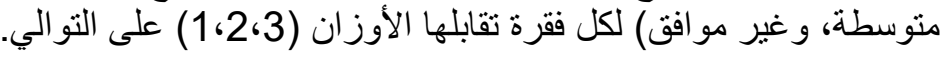

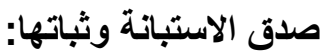

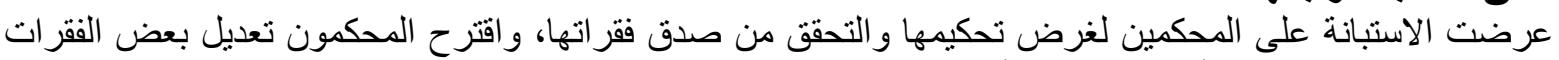
وحذف بعضها الآخر. وللتأكد من ثبات الأداة المعتمدة في البحث تم اختيار عينة ثبات من خارج عينة البنة البحث الاساسية 
بلغت (35) فرداً، واعتمدت طريقة التجزئة النصفية، وحسب معامـــــــلـ ارنباط بيرسون بين درجات النصف الاول

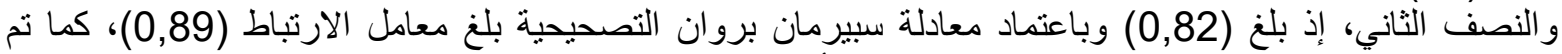

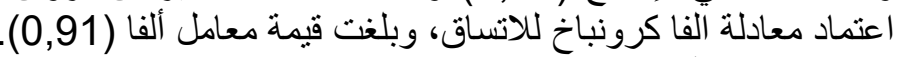

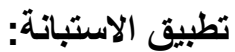

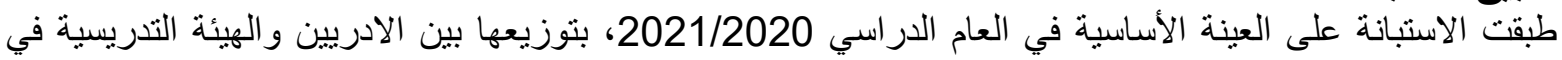

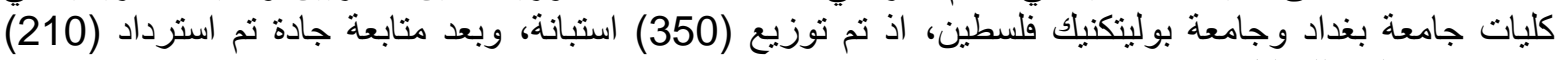
استبانات صالحة للتحليل الإحصائي.

أساليب المعالجة الاحصائية

1- نسبة الموافقة: للتحقق من صلاح كل الإتة فقرة من فقرات الإستبانة.

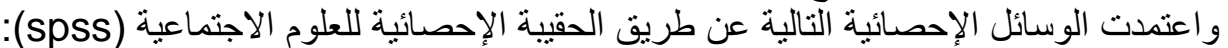

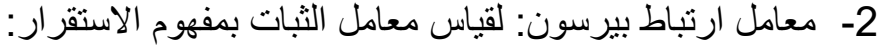

$$
R=\frac{n \sum x y-\sum x \sum y}{\sqrt{\left[n \sum x^{2}\left(\sum x\right)^{2}\right]\left[n \sum y^{2}-\left(\sum y\right)^{2}\right]}}
$$

3- معادلة الفاكرونباخ: لقياس معامل الثبات بمفهوم الاتساق:

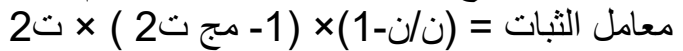

4- معادلة فيشر: لوصف كل فقرة من فقرات أداة البحث ومعرفة قيمتها وترتيبها بالنسبة إلى الفقرات الأخرى ضمن المجال الواحد لعرض النتائج بحسب القانون الآتي:

الوسط

$$
\text { الآوسط المرجح جـ }
$$

$100 \times$

$$
\text { المرجح }
$$

5- الوزن المئوي

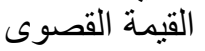

وتم اعتماد وسط فرضي نسبة لأوزان البدائل المعتمدة في الاستبانة على النحو الآتي:

$$
2=\frac{6}{3}=\frac{1+2+3}{3}=\quad \text { الوسط الفرضي }
$$

وبذلك يكون الوسط الفرضي للفقرات هو (2) وما زاد عليه يعد درجة مقبولة، وما يقل عنه يعد درجة غير مقبولة للفقرة.

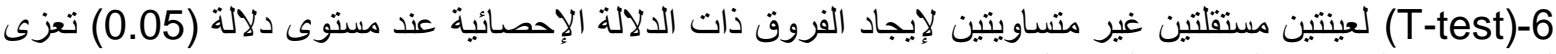

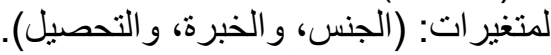

عرض النتائج ومناقشتها:

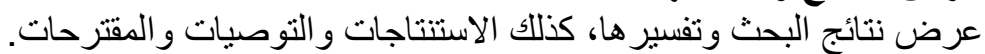

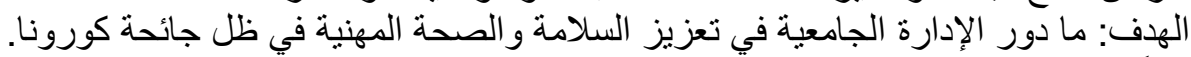

\begin{tabular}{|c|c|c|c|c|c|}
\hline \% الوزن المئوي & المرجط & عدد الفقرات & المجال & $ت$ & المرتبة \\
\hline 80.1 & 2.403 & 10 & الرقابة & 3 & 1 \\
\hline 80.066 & 2.402 & 10 & التقويم & 4 & 2 \\
\hline 79.066 & 2.372 & 10 & التوجيه & 2 & 3 \\
\hline 78.6 & 2.358 & 10 & التخطيط & 1 & 4 \\
\hline 79.433 & 2.383 & 40 & المعدل & & \\
\hline
\end{tabular}
أولاً: النتائج على مستوى الإدارة المجالات:

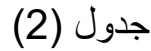
الوسط المرجح و الوزن المئوي لمجالات الاستبانة

يثشير الجدول (2) إلى ان المعدل العام لهذه المجالات الاربعة كان بوسط مرجح (2.383) ووزن فئن مئوي

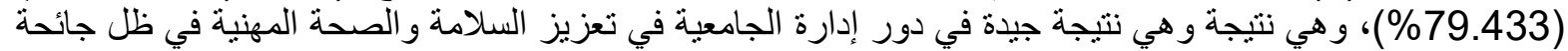

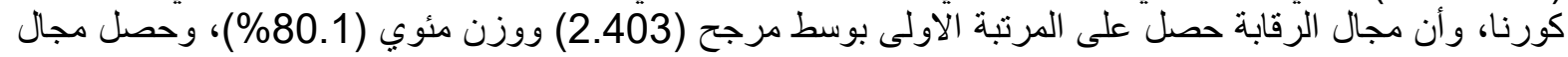




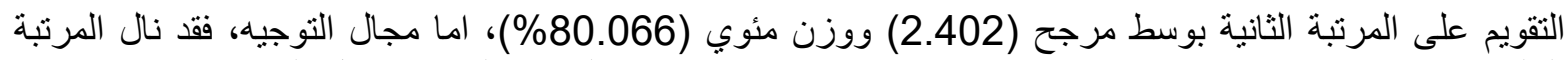

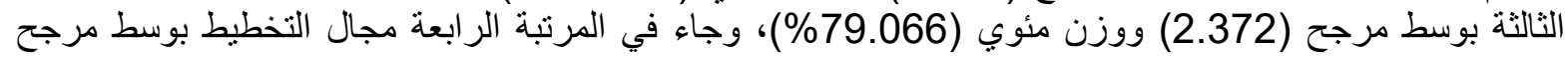
(2.358) ووزن مئوي (78.6\%) (2.37).

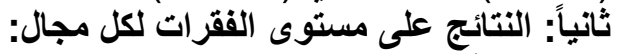

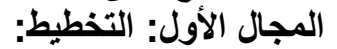
يتضح من الجدول (3) ان هذا المجال يتضمن (10) فقر الت التول.

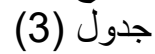

\begin{tabular}{|c|c|c|c|c|}
\hline 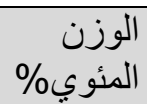 & 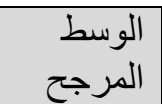 & الفق & ت & 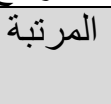 \\
\hline 84.603 & 2.538 & فتح ملف طبي لجميع العاملين قبل ممارستهم للعمل. & 9 & 1 \\
\hline 81.587 & 2.447 & 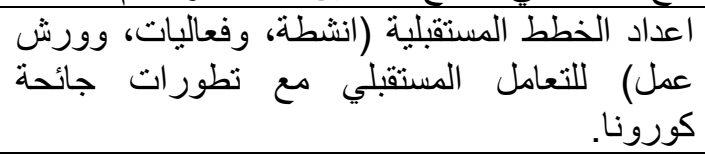 & 6 & 2 \\
\hline 81.587 & 2.447 & التظلامة خطط والصحة وجداول واضحة داخل الجامعة. المعالم في إدارة & 8 & 3 \\
\hline 81.111 & 2.433 & وضكو خطة اللموازنة بين المهام العلمية و إدارة & 1 & 4 \\
\hline 74.444 & 2.233 & تحديد التخصيصة الصحة المهالية في ظل جائحة كورونا. لتمويل إدارة & 5 & 5 \\
\hline 80.793 & 2.423 & 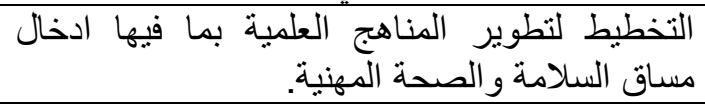 & 2 & 6 \\
\hline 77.142 & 2.3142 & لتنفيذها على ارض ملائمة بالسلامة و والصحة المهنية & 3 & 7 \\
\hline 75.873 & 2.276 & آليات متقدمة في للإفادة من خبرة والصحة المهنية. العليا لوضع & 10 & 8 \\
\hline 74.603 & 2.238 & 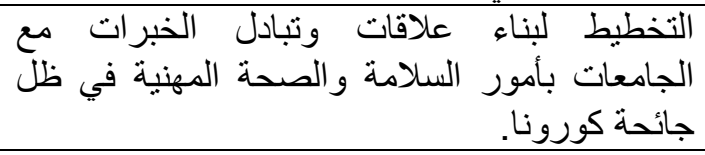 & 7 & 9 \\
\hline 74.444 & 2.233 & 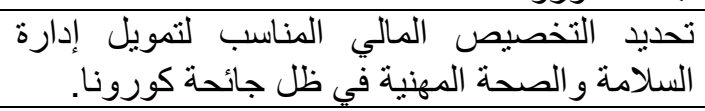 & 5 & 10 \\
\hline 78.6 & 2.358 & الكلية & & \\
\hline
\end{tabular}

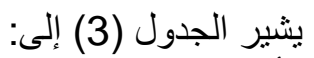
ـ أن الفقرة (938): (فتح ملف طبي لجميع العاملين قبل ممارستهم للعمل) حصلت على المبل المرنبة الاولى بوسط مرجح

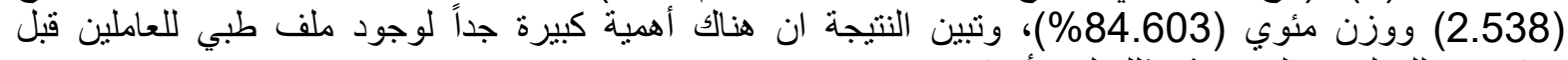

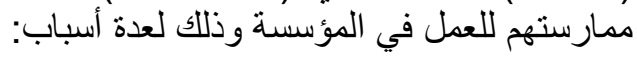

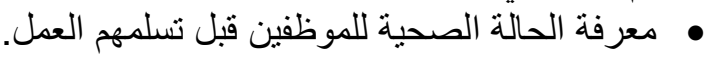

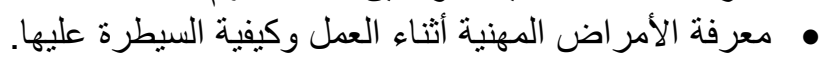

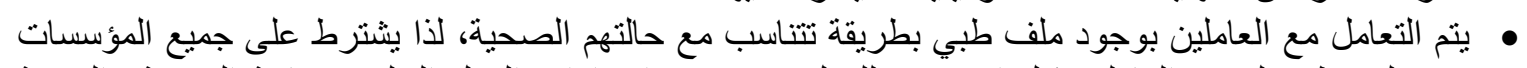
فتح ملف طبي لجميع العاملين قبل استلامهم للعمل من ضمن إجراءات العمل السليم وسياسة السلامة والصحة الصنات

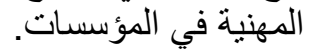

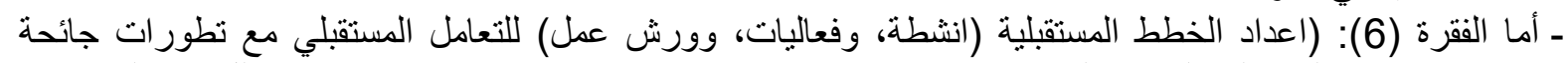

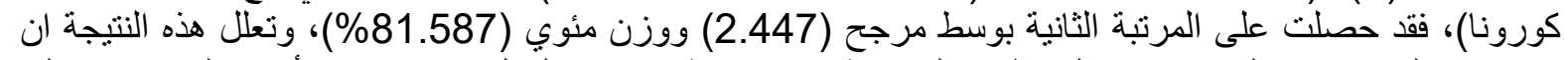
تهنم هذه المؤسسات بالقيام بجميع النشاطات التوعوية والارشادية وورش العمل من ضمن الأمور التي نسعى إلى 
الارتقاء بثقافة العاملين في المؤسسات في أمور السلامة و الصحة المهنية، وهي العلاج الوحيد لتطبيق إجر اءات السلامة

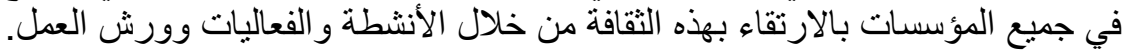

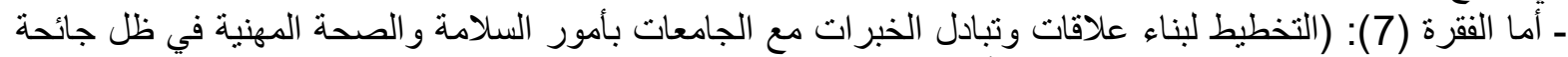

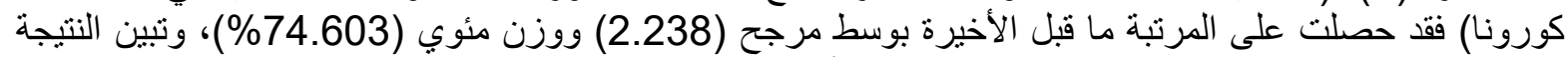

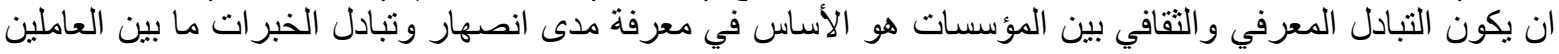

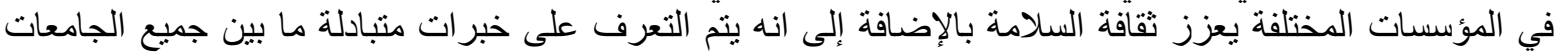

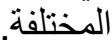
ـ أما الفقرة (5): (تحديد التخصيص المالي المناسب لتمويل إدارة السلامة والصحة المهنية في ظل جائحة كورونا) فقد

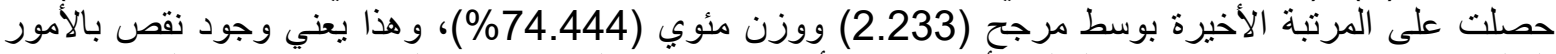

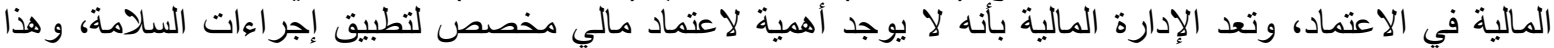

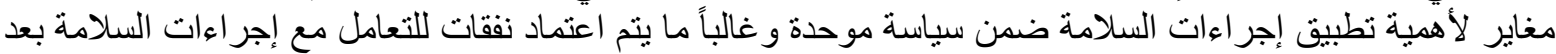

حدوث الحدث لا سمح الله.

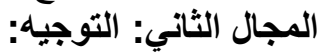
يتضح من الجدول (4) التوجيه: هذان المجال يتضمن (10) فقرات.

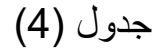
الوسط المرجح والوزن المئوي لفقرات مجال التوجيه

\begin{tabular}{|c|c|c|c|c|}
\hline 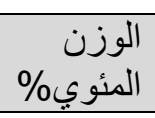 & الوسط المرجح & 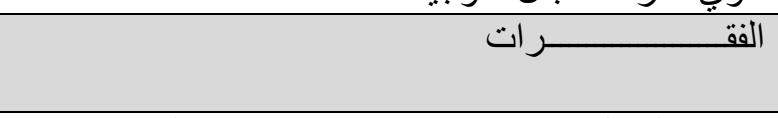 & $ت$ & 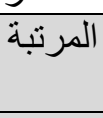 \\
\hline 84.035 & 2.521 & تزويد العاملين بنشرات توعوية وارشادية لرفع مستوى & 3 & 1 \\
\hline 83.650 & 2.509 & والتحققية من الفايروسير بيئة آمنة لجميع منطلبات السلامة & 5 & 2 \\
\hline 81.904 & 2.457 & 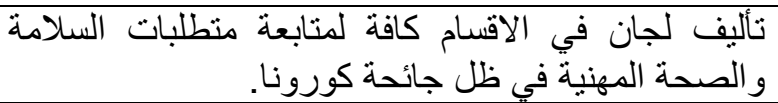 & 8 & 3 \\
\hline 80.476 & 2.414 & تلطوير ثقافة العاملين على وفق اجر اءات السلامة و الصحة & 1 & 4 \\
\hline 77.301 & 2.3190 & 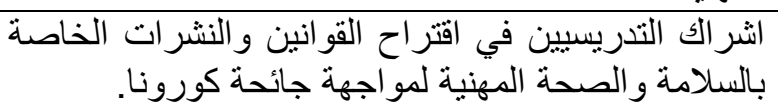 & 7 & 5 \\
\hline 77.142 & 2.314 & 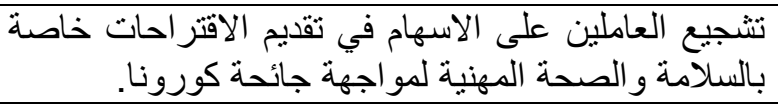 & 4 & 6 \\
\hline 76.984 & 2.309 & كامل لمو اجهة كورونا. & 2 & 7 \\
\hline 76.825 & 2.304 & الموفير الامكانات الفنية لتطبيق اجر اءات السلامة والصحة & 9 & 8 \\
\hline 76.507 & 2.295 & العناسب في المكان المناسب. لكل وظيفة وعمل لوضع الرجل & 10 & 9 \\
\hline 76.031 & 2.281 & في اجراءات السلام. & 6 & 10 \\
\hline 79.066 & 2.372 & الكلية & & \\
\hline
\end{tabular}

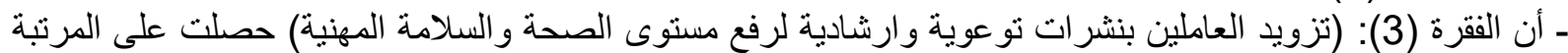

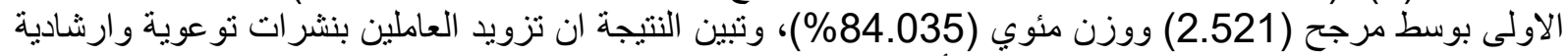

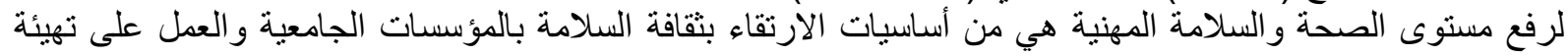

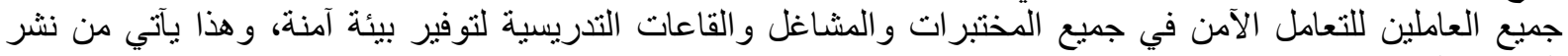
الو الوي و الثقافة.

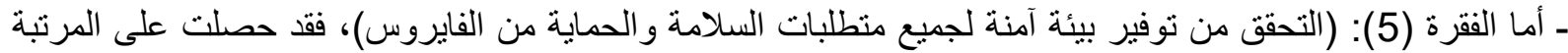

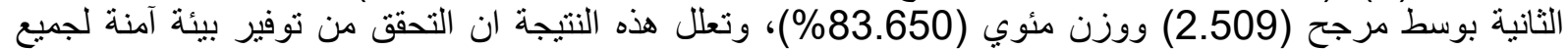

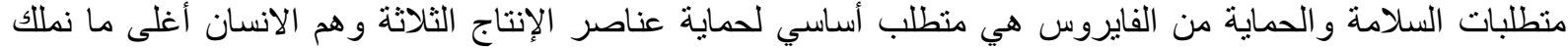
و المعدات و البيئة التعليمية يجب أن تكون ضمن منطلبات السلامة و لا سيمكا في ظل جائحة كورونا. 


\section{THE ROLE OF THE UNIVERSITY ADMINISTRATION IN PROMOTING OCCUPATIONAL SAFETY AND HEALTH IN LIGHT OF THE CORONA PANDEMIC}

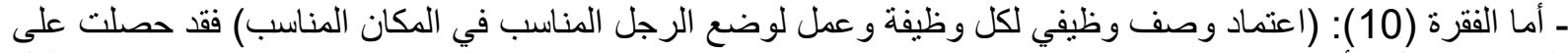

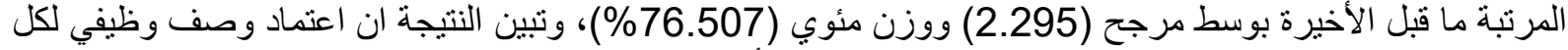

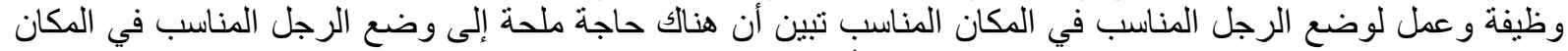

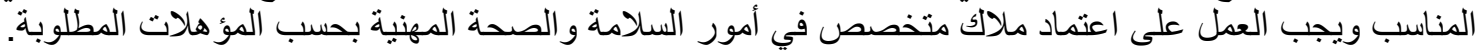

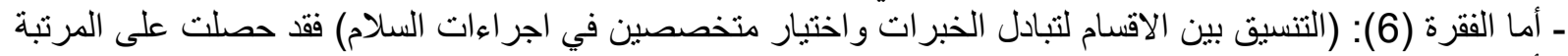

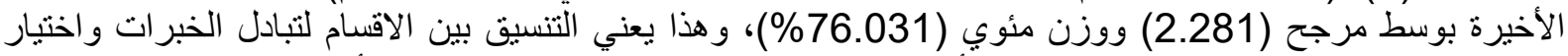

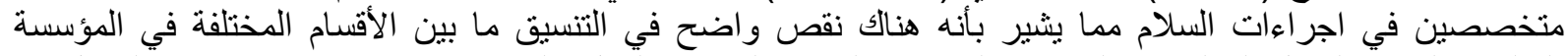

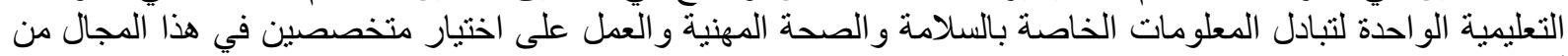
أجل الحصول على بيئة تعليمية آمنة.

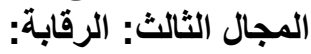
يتضح من الجدول (5) ان هذا المقال: المجال يتضمن (10) فقرات.

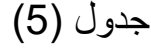

\begin{tabular}{|c|c|c|c|c|}
\hline 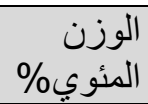 & المرجح & الفق & ت & المرتبة \\
\hline 85.238 & 2.557 & بشأن جائحة كورونات. & 7 & 1 \\
\hline 84.920 & 2.547 & تحوريد اجراءات الرقابة و السلامة عند الإصابة & 1 & 2 \\
\hline 85.238 & 2.557 & وشأن جائحة كورونات محدة لكل قسم بحسب طبيعة عمله & 7 & 3 \\
\hline 83.333 & 2.5 & ظل جائحة كورونا. العاملين في ارتداء معدات الوقاية الثخصية في & 10 & 4 \\
\hline 81.269 & 2.438 & 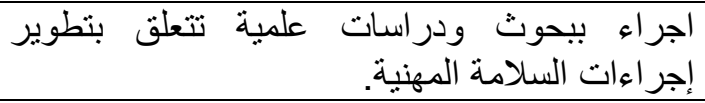 & 8 & 5 \\
\hline 78.095 & 2.342 & ت تثقيف العاملين بتعليمات و القو انين الرقابة والسلامة & 5 & 6 \\
\hline 77.142 & 2.314 & والتحقق من واءتها بنحِِ أمثل العاملين كافة بمعايير الرقابة & 4 & 7 \\
\hline 76.190 & 2.285 & 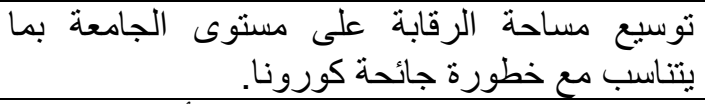 & 3 & 8 \\
\hline 75.396 & 2.261 & وإيقاع عقوبات المهنية. & 9 & 9 \\
\hline 74.444 & 2.233 & و الصيل وتدريب المنية. & 2 & 10 \\
\hline 80.1 & 2.402 & الكلية & & \\
\hline
\end{tabular}

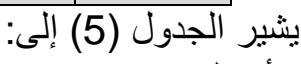

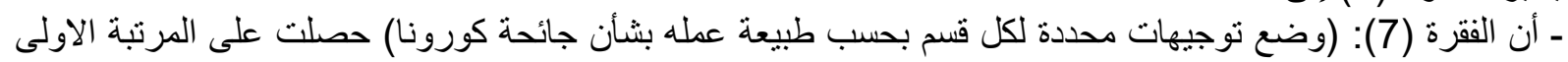

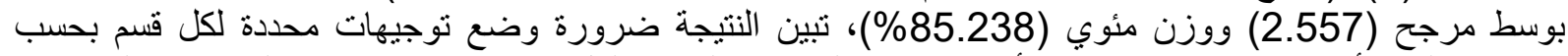

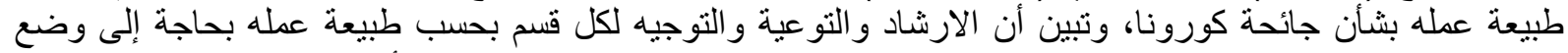

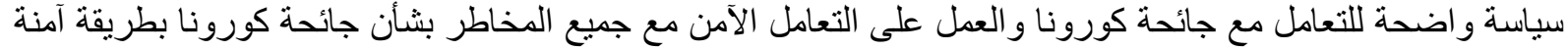

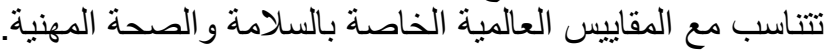

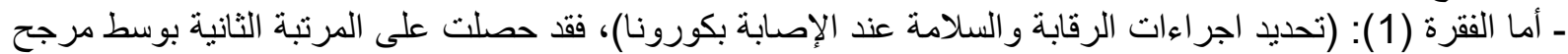

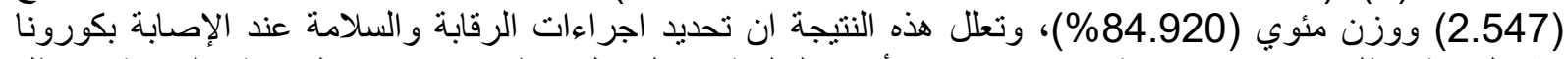

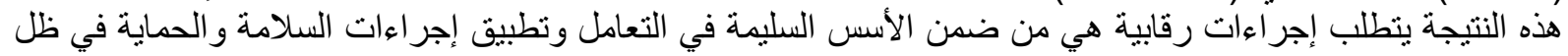


جائحة كورونا والعمل على إيجاد قانون داخلي رقابي يحمل المسؤولية للعاملين في المؤسسات الجامعية من أجل تثبيت إجر اءات العمل السليم في المؤسسات.

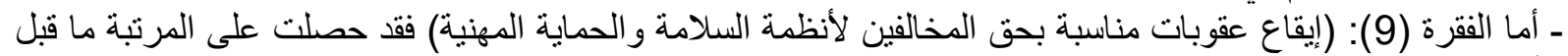

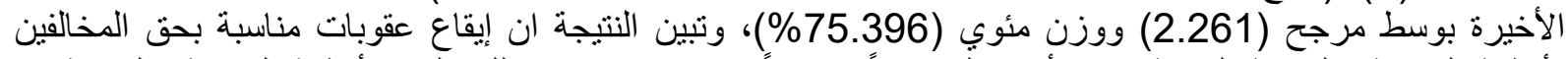

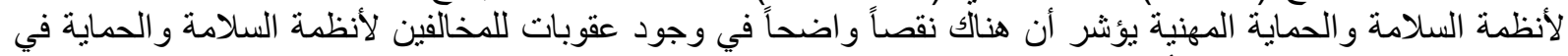

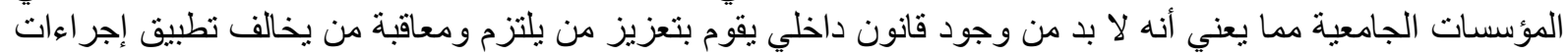
السلامة و الحماية. ـ أما الفقرة (2): (تأهيل وتدريب العاملين لمنطلبات الرقابة والسلامة والصحة المهنية) فقد حصلت على المرتبة العابة الأخيرة

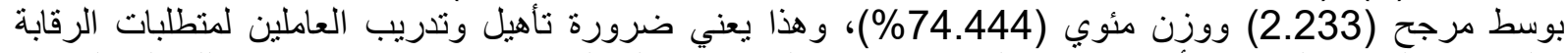

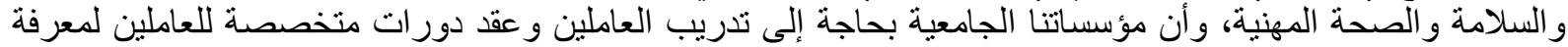

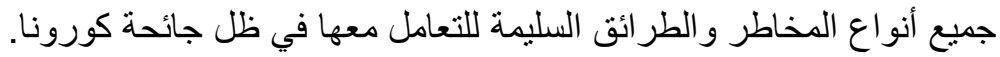

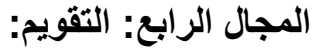
يتضح من الجدول (6) النون: هذا المجال يتضمن (10) فقرات.

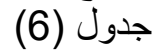

\begin{tabular}{|c|c|c|c|c|}
\hline 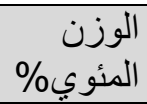 & 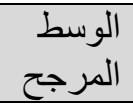 & 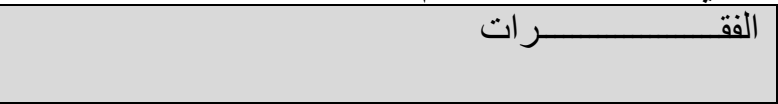 & $ت$ & المرنبة \\
\hline 86.666 & 2.6 & بإجر اءع معات السيلامة وحدة لتقويم العاملين الأكثر تفوقاً و التزامًاً & 6 & 1 \\
\hline 85.555 & 2.566 & وضايروس. معايير و اضحة لتقويم المخاطر الناجمة من & 1 & 2 \\
\hline 84.603 & 2.538 & تشجيع آليات ومعايير لدعم البحث العلمي ذات الصلة & 7 & 3 \\
\hline 82.539 & 2.476 & تقويم مخاطر العمل لمواجية العهة كورونا في ضوء الظروف & 5 & 4 \\
\hline 78.412 & 2.352 & لتقبادل الخبرات بين أقسام الجامعة ومع الجامعات الاخرى & 10 & 5 \\
\hline 78.095 & 2.342 & تنفيذ مجمو عة من النشاطات العلمية لتقويم مستوى الوعي. & 4 & 6 \\
\hline 77.460 & 2.323 & في ظل جائحة كورونا. معي للتقويم خاصاً بالتوجيه والارشاد & 8 & 7 \\
\hline 76.984 & 2.309 & تقويم العاملين في الجامعة في ضوء هورنا. تطبيقات عملية بشأن & 9 & 8 \\
\hline 76.031 & 2.280 & مقاييس السلامة شوط محددة لمباني الجامعة ومر افقها على وفق & 2 & 9 \\
\hline 74.761 & 2.242 & تعريف العاملين بمعايير مخاطر المهنة في العمل & 3 & \\
\hline 80.066 & 2.402 & الكلية & & \\
\hline
\end{tabular}

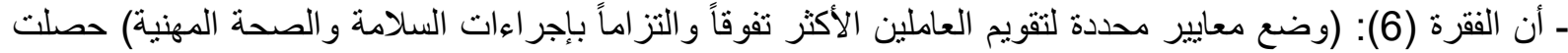

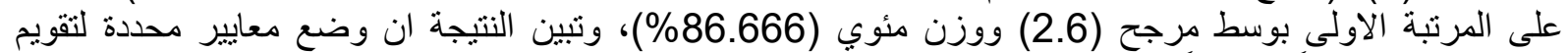

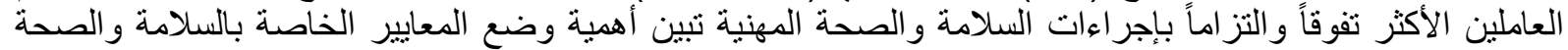

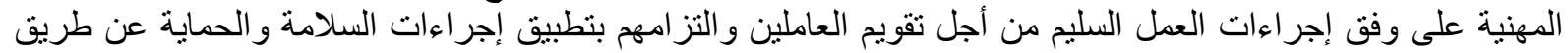

معايير متخصصة في في ذلك ألك.

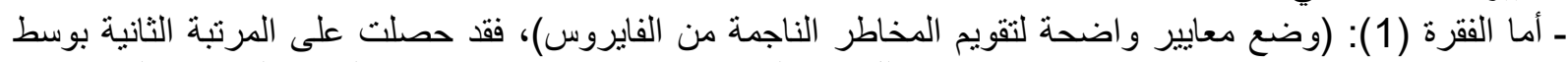

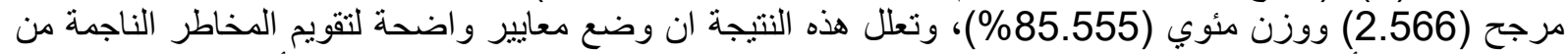
الفايروس تبين أن المخاطر الناتجة عن جائحة كورونا بحاجة إلى وضع النع جميع المعايير الدولية أمام العاملين والطلبة

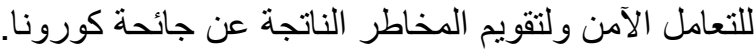

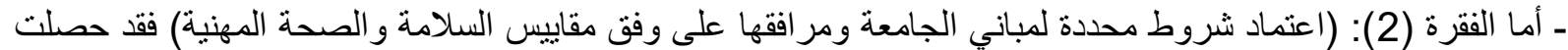
على المرتبة ما قبل الأخيرة بو سط مرجح (2.280) ووزن مئوي (76.031\%)، وتنبين النتيجة ان اعتماد شروط محددة 


\section{THE ROLE OF THE UNIVERSITY ADMINISTRATION IN PROMOTING OCCUPATIONAL SAFETY AND HEALTH IN LIGHT OF THE CORONA PANDEMIC}

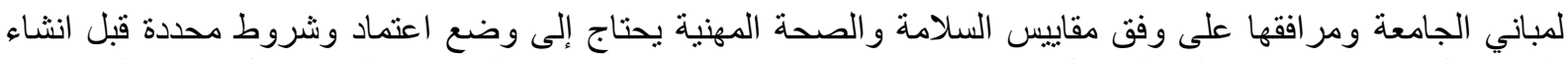

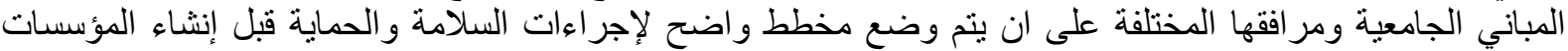
الجامعية و الاهتمام بتطبيقها أثناء عملية الإنشاء.

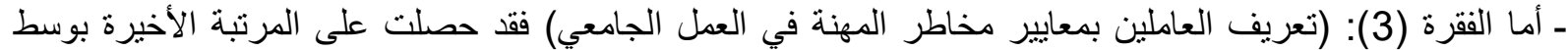

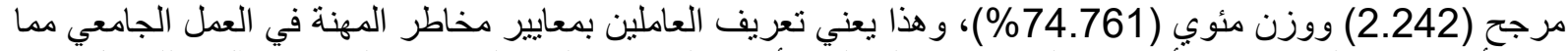

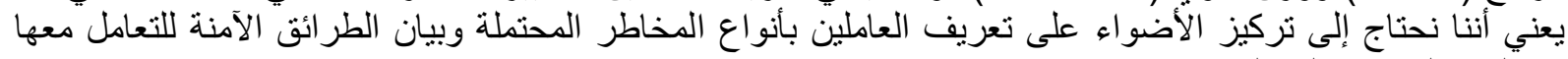
في ألبيئة الجامعية المختلفة.

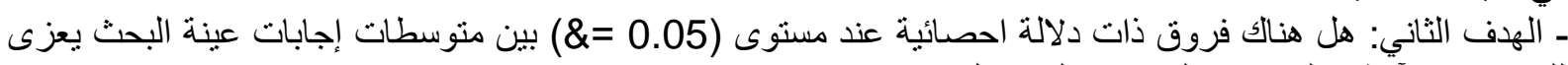

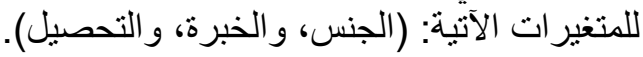

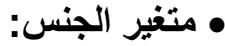

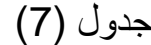

\begin{tabular}{|c|c|c|c|c|c|c|c|}
\hline \multirow{2}{*}{ الاحصائية الالة } & \multicolumn{2}{|c|}{ الاختبار التائي } & \multirow{2}{*}{ الحرية } & \multirow{2}{*}{ الالحعر اف } & \multirow{2}{*}{ الحسابي } & \multirow[b]{2}{*}{ العدد } & \multirow[b]{2}{*}{ الجنس } \\
\hline & الجدولية & المحسوبة & & & & & \\
\hline \multirow{2}{*}{ غير دالة } & \multirow{2}{*}{1.960} & \multirow{2}{*}{1.365} & \multirow{2}{*}{208} & 4.818 & 95.919 & 99 & ذكور \\
\hline & & & & 4.087 & 95.072 & 111 & اناث \\
\hline
\end{tabular}

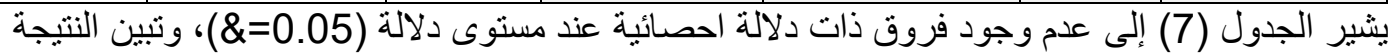

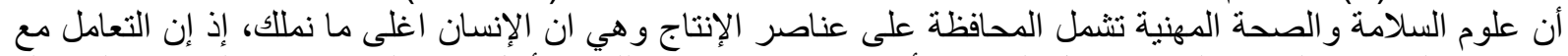

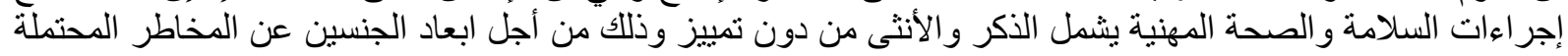
في المؤسسات الجامعية.

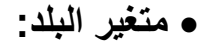

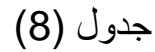

الفروق في مجالات الاستبانة إلى متغير البلد

\begin{tabular}{|c|c|c|c|c|c|c|c|}
\hline \multirow{2}{*}{ الدلالة الاحصائية } & \multicolumn{2}{|c|}{ الاختبار التائي } & \multirow{2}{*}{ الحرية } & \multirow{2}{*}{ الالحعراف } & \multirow{2}{*}{ الحستبي } & \multirow{2}{*}{ 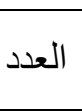 } & \multirow{2}{*}{ البلد البل } \\
\hline & الجدولية & المحسوبة & & & & & \\
\hline \multirow{2}{*}{ غير دالة } & \multirow{2}{*}{1.960} & \multirow{2}{*}{-.348} & \multirow{2}{*}{208} & 4.490 & 95.376 & 117 & العراق \\
\hline & & & & 4.433 & 95.591 & 93 & فلسطين \\
\hline
\end{tabular}

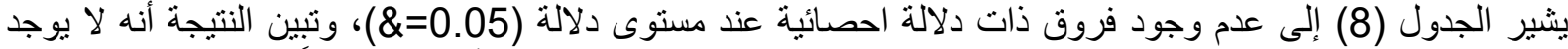

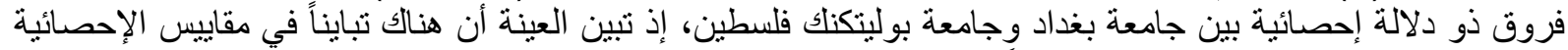

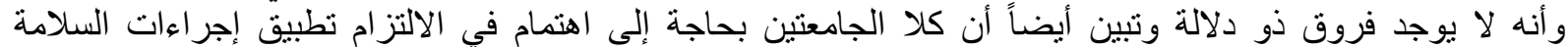
و الحماية ولا سيما في ظل جائحة كورونا.

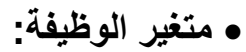

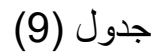

الفروق في مجالات الاستبانة إلى متغير الوظيفة

\begin{tabular}{|c|c|c|c|c|c|c|c|}
\hline \multirow{2}{*}{ الاحصائية } & \multicolumn{2}{|c|}{ الاختبار التائي } & \multirow{2}{*}{ درجة الحرية } & \multirow{2}{*}{ الانحرياري } & \multirow{2}{*}{ الحستبي } & \multirow{2}{*}{ العدد } & \multirow{2}{*}{ التخصص } \\
\hline & الجدولية & المحسوبة & & & & & \\
\hline \multirow[b]{2}{*}{ غير دالة } & \multirow[b]{2}{*}{1.960} & \multirow[b]{2}{*}{.294} & \multirow[b]{2}{*}{208} & 4.453 & 95.550 & 120 & إداري \\
\hline & & & & 4.483 & 95.366 & 90 & تدريسية \\
\hline
\end{tabular}

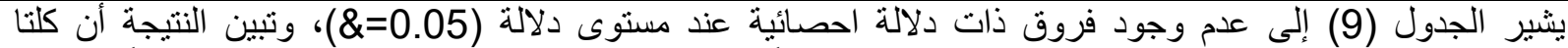

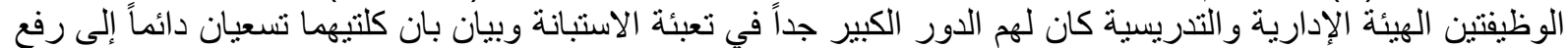

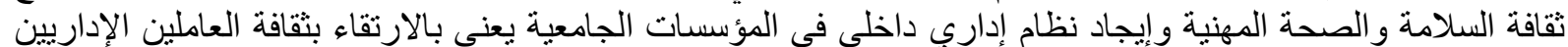

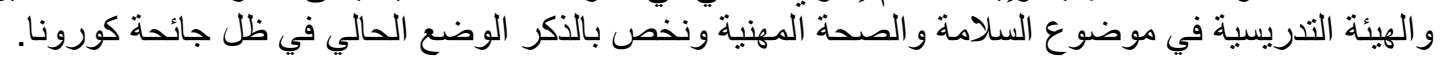




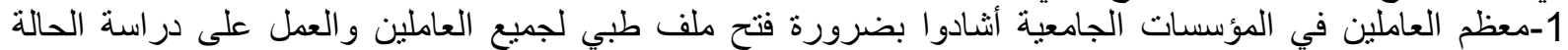

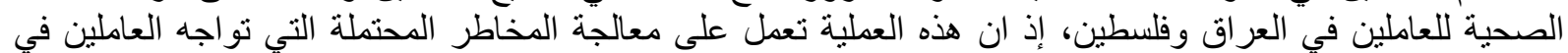

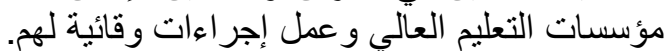

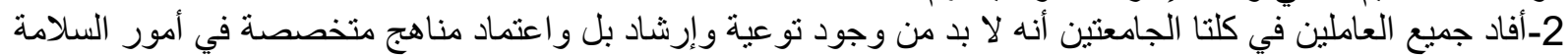

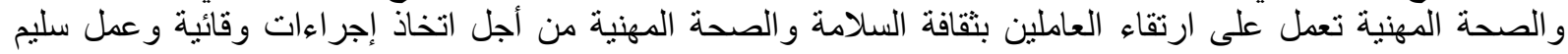
وبيئة تعليمية مناسبة في الجامعات المذكورة العية.

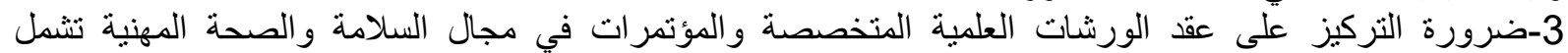

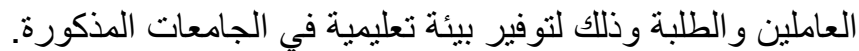

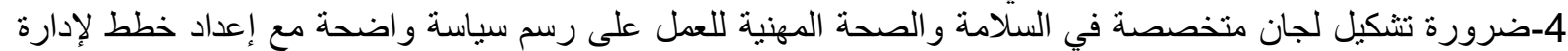
الازمات و الكو ارث بوساطة اللجنة المذكورة و العمل على تطبيقها في المؤسسات الجامعية في ظل جائحة كورونا.

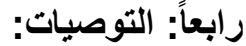
1-يجب أن تسعى كلتا الجامعتين إلى تكثيف ورشات العمل و المؤتمر ات الخاصة بالسلامة و الصحة المهنية وحماية البيئة.

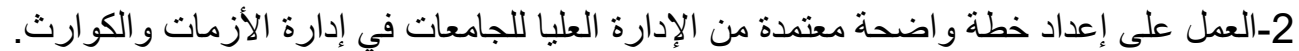

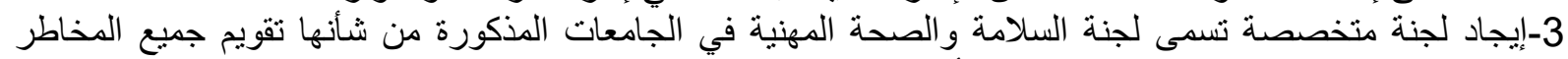

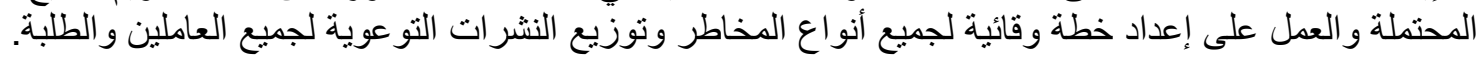

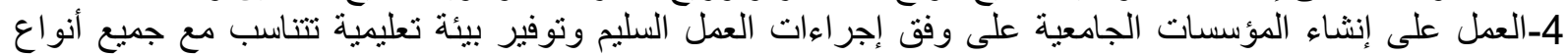
المخاطر وتشمل البيئة التعليمية القاعات التدريسية والمختبرات وات والمشاغل على الملى وفق المقاييس العالمية المتخصصة بالسلامة و الصحة المهنية. 5-العمل على إيجاد موازنة خلية خلاصة مخصصة لتطبيق وتأهيل المؤسسات الجامعية على وفق إجر اءات السلامة و الصحة

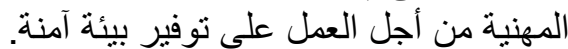

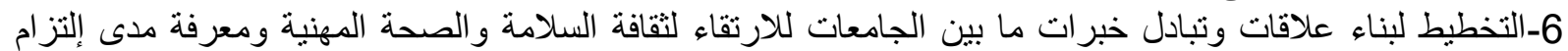

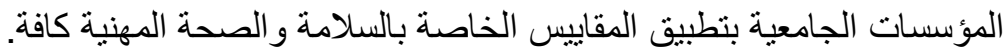

خامساً: المقترحات

يقترح الباحثان إجر اء الداء العات العات المقترحة مستقبلاً:

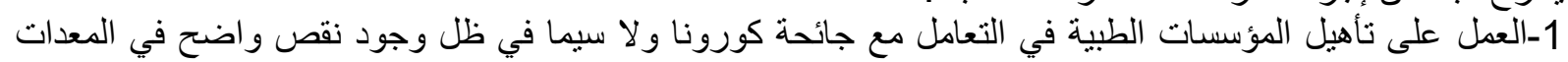

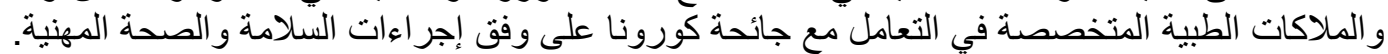

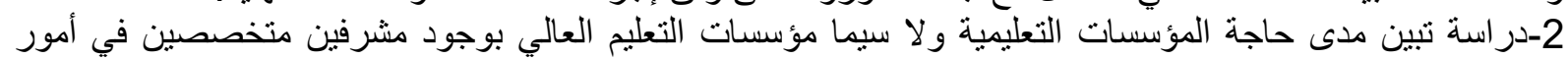
السلامة و الصحة المهنية. 3-دراسة تبين حاجة المؤسسات التعليمية إلى اعتماد مساقات معتمدة ومتخصصة في أمور السلامة والصحة المهنية وحماية البيئة على مستوى الوطن العربي.

احمد، رفعت عبد الغفار و الزلباني، عبد المحسن بن حمدان و الطبيقي، ابو بكر بن عبده (2015):

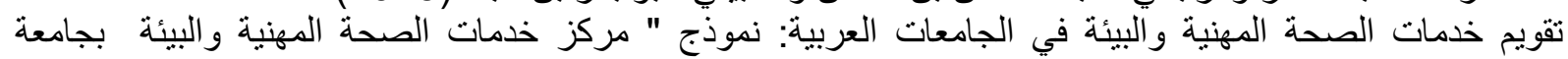

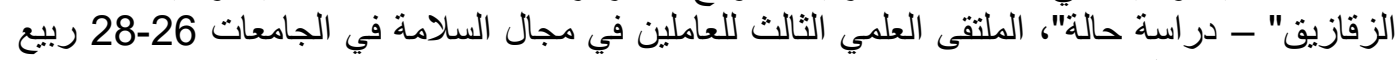

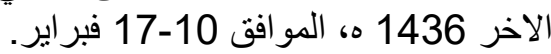

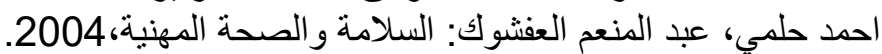

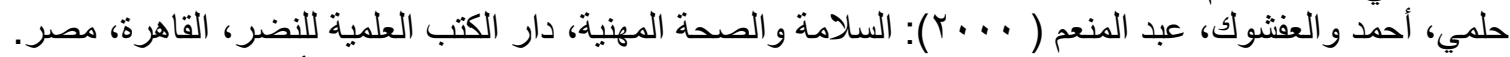
الخطيب , رداح , و آخرون(1998): الإدارة والإشر اف التربوي ( اتجاهات حديثة )، دار الأمل للنشر و التوزيع , الأردن النّا

الرشبدي، مطر( 2006): مدى أهمية تفعيل فرق الدفاع الذآتي في المنشآت الصناعية،رسالة ماجستير (جامعة نايف

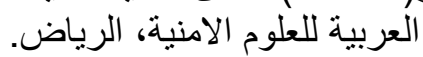

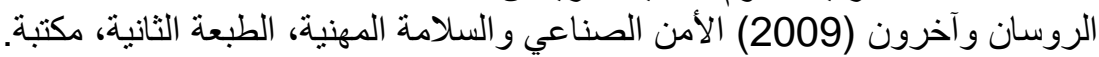

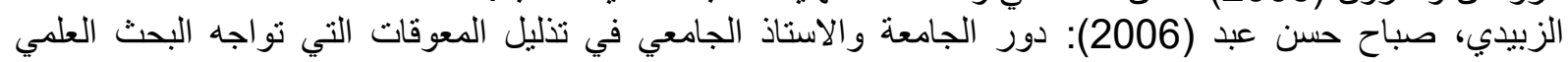

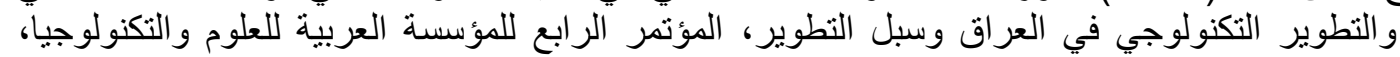
وز ارة التعليم العالي، سوريا. 


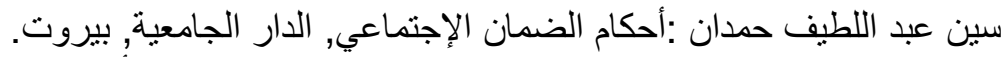

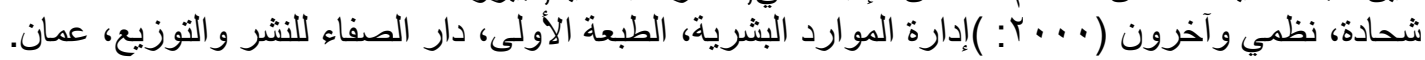

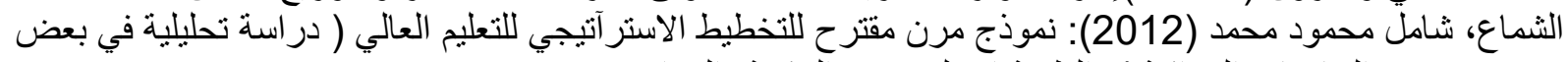

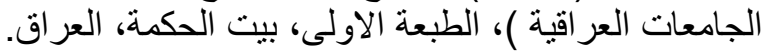

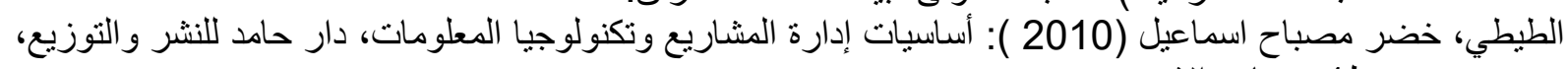

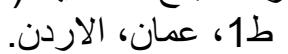

عباس، سهيلة، (2003 ): إدارة المون، ارد البشرية، الطبعة الأولى، دار وائل للنشر، عمان. المجتمع العربي للنشر و التوزيع، عمان. إنوان.

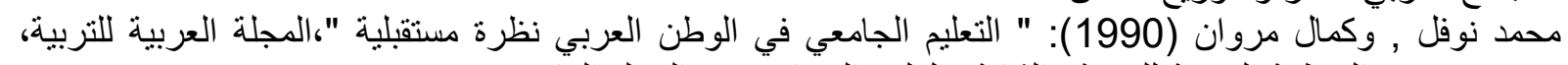

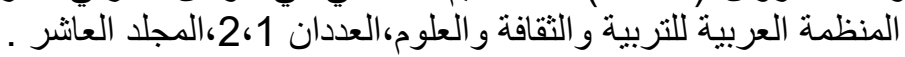

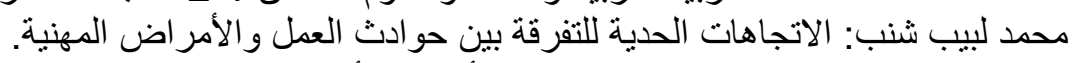

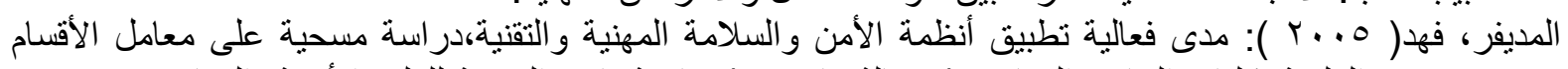

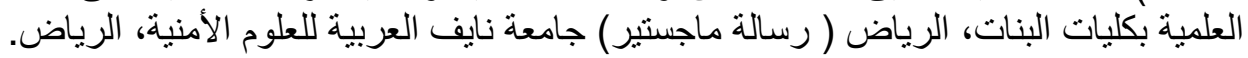

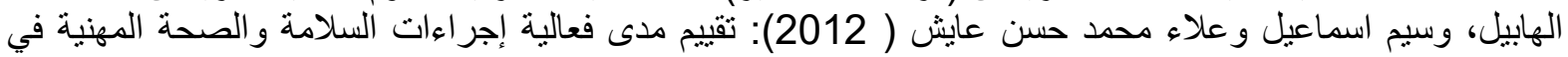
المختبرات العلمية من وجهة نظر العاملين، مجلة الجامعة الإسلامية للادراسات الإقتصادية ولادية والإدارية،

المجلد العشرون، العدد الثاني، فلسطين. 